\title{
Hypertensive disorders of pregnancy
}

\author{
Ana Sjaus, MD · Dolores M. McKeen, MD • Ronald B. George, MD
}

Received: 18 January 2016/Revised: 26 May 2016/ Accepted: 16 June 2016/Published online: 21 July 2016

(C) Canadian Anesthesiologists' Society 2016

\begin{abstract}
Purpose In this continuing professional development module, we review recent Society of Obstetricians and Gynaecologists of Canada (SOGC) guidelines for the classification and diagnosis of hypertensive disorders of pregnancy (HDP) as well as review the clinical features, laboratory investigations, and outcomes of HDP. We explore the evidence for anesthetic management and prevention of end-organ damage in women with HDP and describe the role and contribution of anesthesiologists as part of a multidisciplinary care team.

Principal findings Hypertensive disorders of pregnancy can have variable presentations with clinical signs and symptoms that often do not correlate with the underlying severity and progression of the disease. Failure of timely diagnosis and treatment contributes significantly to adverse maternal (neurologic complications, pulmonary edema, and postpartum hemorrhage) and neonatal (respiratory and neurologic complications and stillbirth) outcomes. In the Canadian context, improvements in medical care have led to better maternal and neonatal outcomes. Timing of delivery is crucial in balancing maternal risks and fetal benefits of ongoing pregnancy. Evidence-based SOGC guidelines regarding diagnosis and management of HDP address many aspects of clinical care
\end{abstract}

Electronic supplementary material The online version of this article (doi:10.1007/s12630-016-0689-8) contains supplementary material, which is available to authorized users.

A. Sjaus, MD - D. M. McKeen, MD $(\varangle) \cdot$ R. B. George, MD Department of Women's \& Obstetric Anesthesia, IWK Health Centre, Faculty of Medicine, Dalhousie University, 5850/5980 University Avenue, P.O. Box 9700, Halifax, NS B3K 6R8, Canada

e-mail: d.mckeen@dal.ca relevant to anesthesiologists, who have an important role in the multidisciplinary care team.

Conclusions Hypertensive disorders of pregnancy are on the rise worldwide, and this trend is expected to continue. The major contributors to maternal mortality are failure to recognize HDP promptly or to treat the condition adequately. It is essential that anesthesiologists understand the disease process and acquire knowledge of the guidelines governing current obstetrical care in order to provide evidence-based multidisciplinary quality care to these patients. Anesthetic management helps prevent potentially deleterious maternal and fetal outcomes.

\section{Objectives of this Continuing Professional Development (CPD) module:}

After reading this module, the reader should be able to:

1. Describe the recent practice guidelines of the Society of Obstetricians and Gynaecologists of Canada (SOGC) regarding the diagnosis and classification of hypertensive disorders of pregnancy (HDP), including clinical features and laboratory investigations.

2. Identify the main maternal and fetal adverse outcomes from pregnancy that are complicated by HDP.

3. Develop an evidence-based approach to the pharmacologic management of hypertension and prevention of end-organ damage in a woman with preeclampsia.

4. Describe the role of the anesthesiologist in the multidisciplinary management of HDP.

5. Review the goals of anesthesia management and the cardiovascular responses to general anesthesia, 
neuraxial analgesia/anesthesia, vasopressors, and uterotonics in women with HDP.

6. Describe the assessment and preparation of a parturient for urgent Cesarean delivery under general anesthesia with anesthetic, obstetrical, and fetal considerations.

7. Describe the postpartum needs of women with preeclampsia.

\section{Overview and incidence}

Hypertensive disorders of pregnancy (HDP) can have multifaceted symptomatology, and can range in severity from a benign disorder that presents in the third trimester to a volatile multisystem disorder that presents early $(<34$ weeks' gestation) and evolves rapidly to severe maternal end-organ dysfunction and fetal compromise.

Worldwide, HDP affect $3-8 \%$ of pregnancies and are significant contributors to maternal and neonatal morbidity and mortality. ${ }^{1}$ In Canada, the rates of HDP have remained relatively stable over the preceding decade (around 5\%). ${ }^{2,3}$ Hypertension without proteinuria, along with preexisting hypertension, has become more frequent, most notably in women with advanced maternal age. ${ }^{2}$ Between 2002 and 2011, 34 parturients died in Canada due to hypertension and related disorders, with an estimated 50 near misses for each death in the same time period. ${ }^{4}$ Given the increasing prevalence of risk factors (e.g., advanced maternal age, obesity, hypertension, and diabetes) in the obstetric population, the rates of HDP are expected to rise in the future. The strongest risk factors for preeclampsia include 1) antiphospholipid syndrome, 2) previous preeclampsia, 3) insulin-dependent diabetes, 4) multiple pregnancy, 5) nulliparity, 6) family history of preeclampsia, 7) obesity, 8) age $>40 \mathrm{yr}$, and 9) preexisting hypertension. ${ }^{5-7}$

Hypertensive disorders of pregnancy place an enormous burden on the affected women, their families, and society. Globally, infants of preeclamptic mothers are at an increased risk of seizures, neonatal encephalopathy, admission to neonatal intensive care, and a twofold higher risk for neonatal death. ${ }^{8}$ In Canada, rates of maternal morbidity and mortality have remained the same despite an increasing incidence of HDP, which is likely evidence of the increasing effectiveness of aggressive medical care. ${ }^{3}$ The increased use of interventions has also led to significant decreases in fetal and infant morbidity and mortality. ${ }^{3}$

\section{Pathophysiology}

A proposed two-stage model of the pathophysiology of preeclampsia links inadequate placental perfusion (first stage) with subsequent development of maternal endothelial dysfunction (second stage), which gives rise to the clinical manifestations of preeclampsia. The first stage may be set in motion by maternal preexisting conditions (microvascular disease from chronic diabetes or hypertension), abnormal placentation with failure of vascular remodeling, or an obstetrical condition of increased placental demand (e.g., multiple gestations). ${ }^{9}$

Normal placentation is characterized by trophoblast invasion into uterine spiral arteries with a resulting decrease in vascular resistance, loss of arteriolar smooth muscle, and terminal vessel dilation -an interaction of maternal and fetal tissues that requires complex immunological mechanisms. The consequence of these changes is an increase in the volume of intervillous space and a decrease in the velocity of blood flow. Failure of normal placentation as described results in a decrease in volume and an increase in the velocity of placental blood flow, which causes placental hypoxia, oxidative stress, and mechanical injury. Syncytiotrophoblasts respond to these conditions by activation of inflammatory and coagulation cascades, and release of a myriad of downstream mediators, including anti-angiogenic proteins (Fig. 1).

Placental dysfunction alone is not enough to produce the syndrome of maternal endothelial cell activation. Research linking the two stages has identified a number of potential biomarkers and targets for diagnosis, treatment, and prevention (e.g., placental growth factor and soluble fmslike tyrosine kinase-1) that are being investigated for clinical use. Despite an increased understanding of their role in preeclampsia, there is a lack of current evidence to support their routine use in clinical practice. ${ }^{5,6}$

Timing of the onset of hypertension in pregnancy may be closely related to underlying pathophysiology. Early- vs. late-onset preeclampsia is generally considered to manifest prior to 34 weeks' gestation. Early-onset disease, with its aggressive course, is associated more strongly with abnormal placental development and restriction of intrauterine growth. In contrast, late-onset preeclampsia (after 34 weeks' gestation) is thought to occur secondary to maternal microvascular diseases (chronic hypertension, diabetes) or maternal genetic disposition and is often associated with near normal fetal growth. ${ }^{10}$ 


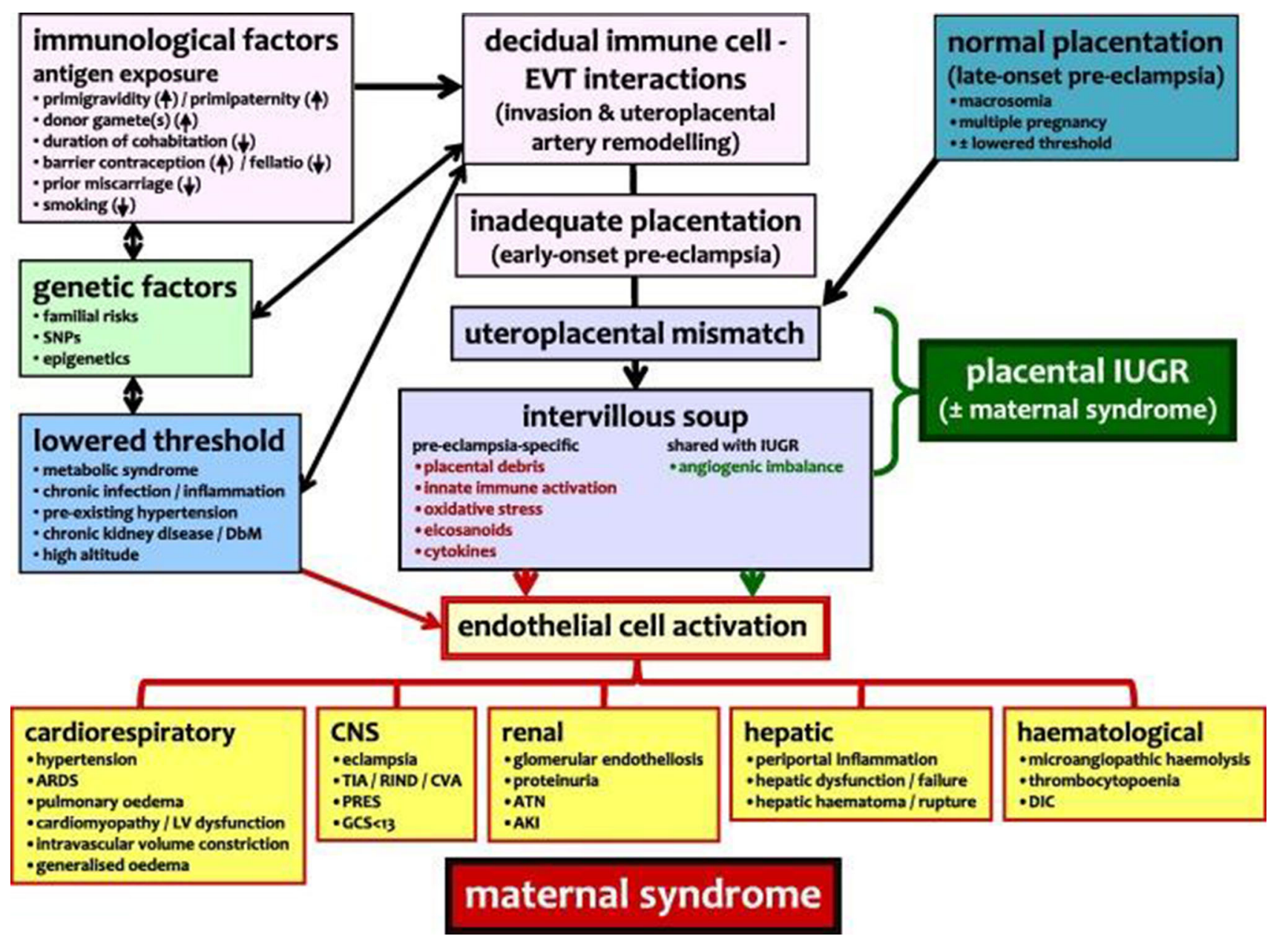

Fig. 1 The origins and consequences of preeclampsia. Adapted with permission from Magee et al. $^{5,6}$ This model of the origins of preeclampsia shows preeclampsia that arises primarily due to imperfect placentation (early-onset or "placental" preeclampsia [pink]) and preeclampsia that arises due to either a lowered maternal threshold or excessive physiological placentation (lateonset or "maternal" preeclampsia [blue]). Some aspects of the preeclampsia process are specific to it, while others are shared with normotensive intrauterine growth restriction. A lowered maternal threshold may influence the development of early-onset preeclampsia as well through direct endothelial cell activation. The consequences of the endothelial cell activation, which appears consistent amongst all women who develop preeclampsia, include a variable impact on multiple vulnerable organ systems. Disease severity generally correlates with the degree and number of organ dysfunctions. ARDS = acute respiratory distress syndrome; AKI = acute kidney injury; $\mathrm{ATN}=$ acute tubular necrosis; $\mathrm{DbM}=$ diabetes mellitus; $\mathrm{DIC}=$ disseminated intravascular coagulation; GCS = Glasgow Coma Scale; IUGR = intrauterine growth restriction; $L V=$ left ventricular; PRES = posterior reversible encephalopathy syndrome; RIND = reversible ischemic neurological deficit; SNP = single nucleotide polymorphism; TIA $=$ transient ischemic attack
Origines et conséquences de la prééclampsie. Adapté avec la permission de Magee et coll. ${ }^{5,6} \mathrm{Ce}$ modèle des origines de la prééclampsie montre une prééclampsie principalement imputable à une placentation imparfaite (prééclampsie d'apparition précoce ou «placentaire»[rose]) et une prééclampsie imputable à un seuil maternel abaissé ou à une placentation physiologique excessive (prééclampsie d'apparition tardive ou « maternelle » [bleu]). Certains des aspects du processus de la prééclampsie lui sont propres, tandis que d'autres sont également constatés dans le cadre d'un retard de croissance intra-utérin normotendu. La présence d'un seuil maternel abaissé pourrait également exercer une influence sur la manifestation d'une prééclampsie d'apparition précoce par l'intermédiaire de l'activation directe des cellules endothéliales. Parmi les conséquences de l'activation des cellules endothéliales qui semblent être constatées chez toutes les femmes qui présentent une prééclampsie, on trouve des effets variables sur de multiples systèmes d'organes vulnérables. La gravité de la maladie est généralement en corrélation avec le degré et le nombre des dysfonctionnements d'organes. AIT = accident ischémique transitoire; $\mathrm{AKI}=$ atteinte rénale aiguë; $\mathrm{CIVD}=$ coagulation intravasculaire disséminée; $\mathrm{DbM}$ = diabète sucré; GCS = Échelle de coma de Glasgow; NTA = nécrose tubulaire aiguë; PRES = syndrome d'encéphalopathie postérieure réversible; RCIU = retard de croissance intra-utérin; RIND = accident ischémique cérébral régressif; SDRA = syndrome de détresse respiratoire aigu; $\mathrm{SNP}=$ polymorphisme mononucléotidique; $\mathrm{VG}=$ ventricule gauche 


\section{Classification and diagnostic criteria}

Clinical practice guidelines

Major national professional bodies in North America and Europe, namely, the American College of Obstetricians and Gynecologists (ACOG) ${ }^{11}$ the Society of Obstetricians and Gynaecologists of Canada (SOGC), ${ }^{5,6}$ and the National Institute for Health and Care Excellence have published diagnostic criteria and management guidelines. ${ }^{12}$ While the classification of hypertension in pregnancy is generally consistent, there are controversial points, including the requirement of proteinuria in the diagnosis of preeclampsia, the thresholds for antihypertensive treatment, as well as the recommendations for magnesium sulfate for seizure prophylaxis.

The SOGC Clinical Practice Guidelines were first published in 2008 and updated in 2014. Notably, the term "pregnancy-induced hypertension" is no longer used in the 2014 version. Hypertensive disorders of pregnancy should now be classified as preexisting hypertension, gestational hypertension, preeclampsia, or "other hypertensive effects" on the basis of different diagnostic and therapeutic considerations. ${ }^{5,6}$ The addition of "other hypertensive effects", including white coat hypertension, recognizes that patients who exhibit hypertension in a medical environment are still at a significantly increased risk of developing gestational hypertension and possibly preeclampsia (Table 1- adopted from Magee et al.). ${ }^{5,6}$

\section{Diagnostic criteria}

The diagnosis of hypertension is unchanged from previous guidelines and is defined as systolic blood pressure (SBP) of $\geq 140 \mathrm{mmHg}$ and/or diastolic blood pressure (DBP) $\geq$ $90 \mathrm{mmHg}$, averaged over two measurements, $15 \mathrm{~min}$ apart,

Table 1 Classification of HDP - adapted from Magee et al..$^{5,6}$

Preexisting hypertension

- With comorbid condition(s)

- With evidence of preeclampsia

Gestational hypertension

- With comorbid condition(s)

- With evidence of preeclampsia

Preeclampsia

Other hypertensive effects

- Transient hypertensive effect

- White coat hypertensive effect

- Masked hypertensive effect
Hypertension was either present pre-pregnancy or developed at $<20$ weeks' gestation

Comorbid conditions (e.g., pre-gestational type 1 or 2 diabetes mellitus or kidney disease) warrant tighter BP control outside of pregnancy because of their association with heightened cardiovascular risk

This is also known as "superimposed preeclampsia" and is defined by the development of one or more of the following at $\geq 20$ weeks:

- Resistant hypertension, or

- New or worsening proteinuria, or

- One/more adverse condition(s), or

- One/more severe complication(s)

This is defined as hypertension that develops for the first time at $\geq 20$ weeks' gestation

Comorbid conditions (e.g., pre-gestational type 1 or 2 diabetes mellitus or kidney disease) warrant tighter BP control outside of pregnancy because of their association with heightened cardiovascular risk

Evidence of preeclampsia may appear many weeks after the onset of gestational hypertension. Preeclampsia is defined by gestational hypertension and one or more of the following:

- New proteinuria, or

- One/more adverse condition(s), or

- One/more severe complication(s)

Preeclampsia may arise de novo. It is defined by gestational hypertension and one or more of the following:

- New proteinuria, or

- One/more adverse condition(s), or

- One/more severe complication(s)

Severe preeclampsia is defined as preeclampsia with one or more severe complications

Elevated BP may be due to environmental stimuli or the pain of labour, for example

$\mathrm{BP}$ that is elevated in the office (SBP $\geq 140 \mathrm{mmHg}$ or $\mathrm{DBP} \geq 90 \mathrm{mmHg}$ ) but is consistently normal outside the office $(<135 / 85 \mathrm{mmHg})$

$\mathrm{BP}$ that is consistently normal in the office $(\mathrm{SBP}<140 \mathrm{mmHg}$ or $\mathrm{DBP}<90 \mathrm{mmHg})$ but is elevated outside the office $(\geq 135 / 85 \mathrm{mmHg})$

$\mathrm{BP}=$ blood pressure $; \mathrm{DBP}=$ diastolic blood pressure; $\mathrm{HDP}=$ hypertensive disorders of pregnancy; $\mathrm{SBP}=$ systolic blood pressure 
and using the same arm. If hypertension is not confirmed on repeat measurement after rest, it is classified as transient. Moderate hypertension is confirmed with $\mathrm{SBP} \geq 150-159 \mathrm{mmHg}$ or DBP $100-109 \mathrm{mmHg}$, and severe hypertension is confirmed with $\mathrm{SBP} \geq 160 \mathrm{mmHg}$ or DBP $\geq 110 \mathrm{mmHg}$. ${ }^{5,6}$

When hypertension is diagnosed in pregnancy, the presence of preeclampsia must be promptly determined, as the subclass of preeclampsia is associated with more adverse maternal and perinatal outcomes. Preeclampsia can arise de novo or can be superimposed on preexisting hypertension or gestational hypertension. Proteinuria is no longer an absolute requirement for the diagnosis of preeclampsia. Proteinuria measurement lacks sensitivity (urine dipstick) and has issues of speed and practicality (24-hr collection for urinary protein, which delays treatment). In addition, severity of proteinuria is not predictive of the severity or outcome of the condition. Instead, given the current knowledge of the multisystem nature of the disease process, if preeclampsia is suspected, even without proteinuria, urgent evaluation for evidence of end-organ dysfunction or "severe features" (e.g., headache or renal dysfunction) is recommended (Table 2).

When a combination of $\boldsymbol{h}$ emolysis, $\boldsymbol{e}$ levation of $\boldsymbol{l}$ iver enzyme, and low platelets (thrombocytopenia) manifest in a pregnant patient, HELLP syndrome is likely present. Although widely considered alongside other hypertensive disorders of pregnancy, proteinuria and hypertension may be absent. A number of medical conditions with similar features can mimic the presentation of HELLP syndrome, for example, fatty liver of pregnancy and idiopathic thrombocytopenic purpura. ${ }^{13}$

Table 2 Adverse conditions and severe complications of preeclampsia - adapted from Magee et al. . $^{5,6}$

\begin{tabular}{|c|c|c|}
\hline $\begin{array}{l}\text { Organ system } \\
\text { affected }\end{array}$ & $\begin{array}{l}\text { Adverse conditions (that increase } \\
\text { the risk of severe complications) }\end{array}$ & $\begin{array}{l}\text { Severe complications } \\
\text { (that warrant delivery) }\end{array}$ \\
\hline CNS & - Headache/visual symptoms & $\begin{array}{l}\text { - Eclampsia } \\
\text { - PRES (posterior reversible leukoencephalopathy) } \\
\text { - Cortical blindness or retinal detachment } \\
\text { - Glasgow coma scale }<13 \\
\text { - Stroke, TIA, or RIND }\end{array}$ \\
\hline Cardiorespiratory & $\begin{array}{l}\text { - Chest pain / dyspnea } \\
\text { - Oxygen saturation }<97 \%\end{array}$ & $\begin{array}{l}\text { - Uncontrolled severe hypertension (over a period of } \\
12 \mathrm{hr} \text { despite use of three antihypertensive agents), } \\
\text { - Oxygen saturation }<90 \% \text {, need for } \geq 50 \% \text { oxygen } \\
\text { for }>1 \mathrm{hr} \text {, intubation (other than for Cesarean } \\
\text { delivery), pulmonary edema } \\
\text { - Positive inotropic support } \\
\text { - Myocardial ischemia or infarction }\end{array}$ \\
\hline Hematological & $\begin{array}{l}\text { - Elevated WBC count } \\
\text { - Elevated INR or aPTT } \\
\text { - Low platelet count }\end{array}$ & $\begin{array}{l}\text { - Platelet count }<50 \times 10^{-9} \cdot \mathrm{L}^{-1} \\
\text { - Transfusion of any blood product }\end{array}$ \\
\hline Renal & $\begin{array}{l}\text { - Elevated serum creatinine } \\
\text { - Elevated serum uric acid }\end{array}$ & $\begin{array}{l}\text { - Acute kidney injury (creatinine }>150 \mu \mathrm{Mol} \cdot \mathrm{L}^{-1} \text { with } \\
\text { no prior renal disease) } \\
\text { - New indication for dialysis }\end{array}$ \\
\hline Hepatic & $\begin{array}{l}\text { - Nausea or vomiting } \\
\text { - RUQ or epigastric pain } \\
\text { - Elevated serum AST, ALT, LDH, or bilirubin } \\
\text { - Low plasma albumin }\end{array}$ & $\begin{array}{l}\text { - Hepatic dysfunction (INR }>2 \text { in absence of DIC or warfarin) } \\
\text { - Hepatic hematoma or rupture }\end{array}$ \\
\hline Fetoplacental & $\begin{array}{l}\text { - Non-reassuring FHR } \\
\text { - IUGR } \\
\text { - Oligohydramnios } \\
\text { - Absent or reversed end-diastolic } \\
\quad \text { flow by Doppler velocimetry }\end{array}$ & $\begin{array}{l}\text { - Placental abruption with evidence of maternal or fetal compromise } \\
\text { - Reverse ductus venosus A wave } \\
\text { - Stillbirth }\end{array}$ \\
\hline
\end{tabular}

aPTT $=$ activated partial thromboplastin time; ALT = alanine aminotransferase; AST = aspartate aminotransferase; CNS = central nervous system; DIC = disseminated intravascular coagulation; FHR = fetal heart rate; INR = international normalized ratio; IUGR = intrauterine growth restriction; LDH = lactate dehydrogenase; RIND = reversible ischemic neurological deficit; RUQ = right upper quadrant; TIA = transient ischemic attack; $\mathrm{WBC}=$ white blood cell 
Risk stratification and predictors of outcome

In patients with HDP, the risk of adverse maternal or perinatal outcomes is increased when early preeclampsia ( $<34$ weeks' gestation) or certain maternal adverse conditions develop as a result of widespread endothelial dysfunction (Table 2). ${ }^{5,6}$ These conditions include headache, chest pain or dyspnea, decreased oxygen saturation, thrombocytopenia, or elevated levels of creatinine or aspartate aminotransferase.

Patients who develop HELLP syndrome are at high risk of severe complications, such as placental abruption (16\%), disseminated intravascular coagulation (DIC) (20\%), and acute renal failure $(8 \%){ }^{13}$ Maternal mortality has been reported at $1 \%$ and neonatal mortality as high as $34 \%$ when delivered before 34 weeks' gestation. ${ }^{14}$ Patients with HELLP syndrome can deteriorate rapidly and show delayed recovery, and symptoms often worsen after delivery.

\section{Obstetric management}

Care location and pathways

While patients with severe hypertension or severe preeclampsia should be admitted for inpatient care, bed rest does not seem to alter disease severity and is not recommended. ${ }^{5,6}$

Mode of delivery

Vaginal delivery should be the goal, with Cesarean delivery considered for the usual obstetrical and neonatal

Table 3 Emergent therapy for acute-onset severe hypertension during pregnancy and the postpartum period using one of three first-line antihypertensives - adapted from ACOG Committee Opinion ${ }^{13}$

\begin{tabular}{lll}
\hline Initial First-Line Management With & Initial First-Line Management With & $\begin{array}{l}\text { Initial First-Line Management With } \\
\text { Oabetalol }\end{array}$ \\
Hydralazine & Oral Nifedipine
\end{tabular}

Notify physician if systolic blood pressure (BP) measurement is greater than or equal to $160 \mathrm{mmHg}$ or if diastolic BP measurement is greater than or equal to $110 \mathrm{mmHg}$. Institute fetal surveillance if undelivered and fetus is viable.

- If severe BP elevations persist for $15 \mathrm{~min}$ or • If severe BP elevations persist for $15 \mathrm{~min}$ or • If severe BP elevations persist for 15 min or more, administer labetalol (20 mg $i v$ over 2 more, administer hydralazine (5mg or $10 \mathrm{mg}$ $\min )$.

record results.

- If either BP threshold is still exceeded, administer labetalol (40 $\mathrm{mg}$ iv over $2 \mathrm{~min}$ ). If $\mathrm{BP}$ is below threshold, continue to monitor BP closely.

- Repeat BP measurement in $10 \mathrm{~min}$ and record results.

- If either BP threshold is still exceeded, administer labetalol (80 mg iv over $2 \mathrm{~min}$ ). If $\mathrm{BP}$ is below threshold, continue to monitor BP closely.

- Repeat BP measurement in 10 min and record results.

- If either BP threshold is still exceeded, administer hydralazine $(10 \mathrm{mg} i v$ over 2 $\mathrm{min})$. If $\mathrm{BP}$ is below threshold, continue to monitor BP closely.

- Repeat BP measurement in 20 min and record results.

- If either BP threshold is still exceeded, obtain emergency consultation from maternal-fetal medicine, internal medicine, anesthesia, or critical care subspecialists. iv over $2 \mathrm{~min}$ ).

- Repeat BP measurement in 20 min and record results.

more, administer nifedipine (10 mg capsules should be administered orally and not punctured or

otherwise administered sublingually).

- If either BP threshold is still exceeded, administer hydralazine $(10 \mathrm{mg} i v$ over 2 $\mathrm{min}$ ). If BP is below threshold, continue to monitor BP closely.

- Repeat BP measurement in 20 min and record results.

- If either BP threshold is still exceeded, administer labetalol (20 mg iv over $2 \mathrm{~min}$ ). If $\mathrm{BP}$ is below threshold, continue to monitor BP closely.

- Repeat BP measurement in $10 \mathrm{~min}$ and record results.

- If either BP threshold is still exceeded, administer labetalol

(40 mg $i v$ over $2 \mathrm{~min}$ ) and obtain emergency consultation from maternal-fetal medicine, internal medicine, anesthesia, or critical care subspecialists.
- Repeat BP measurement in $20 \mathrm{~min}$ and record results.

- If either BP threshold is still exceeded, administer nifedipine capsules $(20 \mathrm{mg}$ orally). If $\mathrm{BP}$ is below threshold, continue to monitor BP closely.

- Repeat BP measurement in $20 \mathrm{~min}$ and record results.

- If either BP threshold is still exceeded, administer nifedipine capsule $(20 \mathrm{mg}$ orally). If BP is below threshold, continue to monitor BP closely.

- Repeat BP measurement in $20 \mathrm{~min}$ and record results.

- If either BP threshold is still exceeded, administer labetalol (40 $\mathrm{mg}$ iv over $2 \mathrm{~min}$ ) and obtain emergency consultation from maternal-fetal medicine, internal medicine, anesthesia, or critical care subspecialists.

Once the aforementioned BP thresholds are achieved, repeat BP measurement every ten minutes for one hour, then every 15 min for one hour, then every $30 \mathrm{~min}$ for one hour, and then every hour for four hours

ACOG $=$ American College of Obstetricians and Gynecologists 
indications. ${ }^{5,6}$ Recommendations for intra and immediate postpartum management include active management of the third stage of labour (parenteral oxytocin administration), continuation of antihypertensive therapy throughout labour and delivery, and consideration for avoiding ergometrine in the treatment of uterine atony.

\section{Timing of delivery}

Delivery of the placenta is the only cure for preeclampsia; therefore, the decision to deliver is based on the balance between the maternal and fetal risks of continuing the pregnancy and the neonatal risks of delivery. ${ }^{15}$ Consensusderived indications that warrant delivery include term gestation, development of severe maternal HDP-associated complication(s), stillbirth, or fetal monitoring that indicates delivery according to general obstetric practice. ${ }^{5,6}$ For women with preeclampsia at term ( $>37$ weeks' gestation), immediate delivery is strongly recommended. ${ }^{16}$ All women with severe preeclampsia warrant delivery regardless of gestational age. Women with HELLP syndrome presenting after 35 weeks should be strongly considered for immediate delivery, and at $24-34^{+6}$ weeks, delivery should be delayed for administration of antenatal corticosteroids. ${ }^{5}$

Expectant management may benefit those with nonsevere preeclampsia at $24-33^{+6}$ weeks. New evidence from the 2015 HYPITAT-II trial ("Immediate delivery versus expectant monitoring for hypertensive disorders of pregnancy between 34 and 37 weeks of gestation"), published after the 2014 SOGC guidelines, found that immediate delivery might reduce the small risk of maternal complications, but in the expectant monitoring group, prolongation of pregnancy by as little as five days significantly reduced the risk of neonatal respiratory distress. ${ }^{17}$

\section{Goal of antihypertensive therapies}

The goal of treatment is to control hypertension while preserving placental and maternal end-organ perfusion. There is less agreement amongst the guidelines regarding the threshold for treatment and the target BP. The SOGC guidelines advocate treatment of moderate as well as severe maternal hypertension. The target BP is a matter of some controversy, the concern being that aggressive lowering may lead to maternal and fetal compromise. The SOGC treatment goals suggest lowering SBP to $130-155 \mathrm{mmHg}$, DBP to $80-105 \mathrm{mmHg}$ in patients with non-severe hypertension, and BP to below 140/90 $\mathrm{mmHg}$ in those with comorbidities. Severe hypertension requires urgent treatment with the goal to reduce BP to below 160/110 $\mathrm{mmHg}$.
Magnesium sulfate

\section{Prevention of seizures}

Eclampsia, defined as the occurrence of grand mal seizures in pregnant women with underlying preeclampsia, can be the presenting feature of HDP. It is associated with serious morbidity (e.g., renal failure, pulmonary edema, aspiration pneumonia, stroke, and cardiopulmonary arrest) and maternal mortality in the range of $1 \%$.

Magnesium sulfate is superior to all other agents in the prophylaxis of eclampsia. It significantly reduces the occurrence of seizures by more than $50 \%^{5,6}$ through a mechanism of action that is likely multifactorial: calcium antagonist relaxation of vascular smooth muscle, causing vasodilation that may lower total vascular resistance; decrease in cerebral endothelial permeability via calciumdependent second messenger systems, thus decreasing vasogenic edema; and lastly, anticonvulsant activity by increasing the seizure threshold through inhibition of the N-methyl-D-aspartate receptor. ${ }^{18}$

The number needed to treat to prevent seizures is 50 in severe preeclampsia and 100 in non-severe preeclampsia. The current SOGC guidelines strongly recommend magnesium sulfate as prophylaxis against eclampsia for women with severe preeclampsia as well as for women with non-severe preeclampsia who also exhibit severe hypertension, evidence of end-organ dysfunction, or a platelet count $<100 \times 10^{-9} \cdot \mathrm{L}^{-1}$. Standard magnesium sulfate dosing should be a $4 \mathrm{~g}$ intravenous loading dose followed by an infusion of $1 \mathrm{~g} \cdot \mathrm{hr}^{-1}$. Serum magnesium levels are not necessary if the patient is clinically monitored for signs of toxicity -unless there is oliguria due to renal dysfunction, which will reduce magnesium excretion and potentially lead to elevated serum levels. ${ }^{5,6}$

\section{Management of seizures}

In addition to being recommended as a prophylactic agent, a $4 \mathrm{~g}$ magnesium sulfate bolus is recommended as the firstline treatment in the event of eclamptic seizures. ${ }^{11}$ Among women with eclampsia, magnesium sulfate infusion should be continued during delivery and $24 \mathrm{hr}$ after the last convulsion. Benzodiazepines and phenytoin are reserved for cases where magnesium sulfate is contraindicated or ineffective. ${ }^{5,6}$ There is general agreement that women with eclampsia warrant delivery following initial stabilization.

Neonatal neuroprotection is a relatively recent indication for maternal administration of magnesium sulfate in the setting of imminent preterm birth (within the next $24 \mathrm{hr}$ ) at $\leq 31^{+6}$ weeks, provided emergent delivery is not delayed by administration. ${ }^{5,6}$ 


\section{Anesthetic management}

\section{General principles}

Effective communication between multidisciplinary caregivers is essential. ${ }^{5,6}$ An early consultation with the anesthesiologist is recommended for all women with preeclampsia. $^{5,6,11}$ Important aspects of overall care that anesthesiologists provide to women with HDP include labour analgesia, control of hypertension, anesthetic care for urgent operative delivery, intravascular volume management, administration of blood components, and invasive monitoring.

\section{Hypertensive emergencies}

The ACOG Committee Opinion published in 2015 specifically addresses the treatment of severe hypertension and hypertensive emergencies. ${ }^{13}$ The degree of systolic hypertension is the most important predictor of cerebral injury and infarction: in a case series, SBP $>160$ $\mathrm{mmHg}$ was reported present in more than $95 \%$ of severely preeclamptic patients immediately pre-stroke. ${ }^{19}$ Acuteonset severe hypertension $(>160 / 110)$ that persists for at least $15 \mathrm{~min}$ is considered a hypertensive emergency when associated with end-organ dysfunction. Immediate fetal monitoring and pharmacologic therapy is indicated to achieve a BP range of $140-150 / 90-100 \mathrm{mmHg}$ to minimize exposure to severe systolic hypertension and loss of cerebral autoregulation (Table 3).

The initial choice of antihypertensive for the treatment of severe hypertension has traditionally relied on adrenergic blockade with either labetalol or hydralazine. North American guidelines add oral short-acting calcium channel blockade with nifedipine 5-10 mg capsules as an additional first-line option for in-hospital treatment and suggest that a more rapid reduction in SBP may be achieved as compared with intravenous labetalol and hydralazine. ${ }^{11}$ An additional antihypertensive agent should be administered if successive doses of one agent fail to bring the $\mathrm{BP}$ into the target range.

The ACOG describes three protocols for the treatment of a hypertensive emergency. Each protocol starts with the initial drug (labetalol, hydralazine, or oral rapid-acting nifedipine) then adds successive second and third agents. While neither the ACOG nor the SOGC guidelines recommend specifically against the combination of hydralazine and nifedipine, the potential for hydralazine to cause more maternal hypotension than labetalol is clearly stated. ${ }^{11}$ The SOGC guidelines indicate that uncontrolled severe hypertension (over $12 \mathrm{hr}$ despite the use of three antihypertensive agents) warrants immediate delivery. ${ }^{5,6}$
For severe cases of refractory hypertension treated in a hospital setting, sodium nitroprusside infusions may be used as alternative agent provided maternal and fetal exposure is limited as much as possible to reduce the risk of cyanide toxicity. ${ }^{5,6,11}$ Magnesium sulfate alone is not a sufficiently effective antihypertensive and should not be used for primary BP control in HDP. While initial case reports of respiratory depression and neuromuscular blockade raised concerns regarding concurrent administration of calcium channel blockers and magnesium sulfate, more recent reviews suggest that these concerns are not justified and co-administration is safe in an inpatient setting. ${ }^{6,20-22}$

\section{Management of seizures}

Anesthesiologists (with the ability to support the airway) frequently provide care in the management of acute seizures in women with eclampsia. Anesthesiologists may use an intravenous bolus of propofol $0.5-1 \mathrm{mg} \cdot \mathrm{kg}^{-1}$ or midazolam 2-4 mg for rapid termination of seizures in the general population. While anesthesiologists are familiar with their use, there is no published evidence available to guide the use of midazolam or propofol in eclampsia. Standard anesthesia textbooks note the potential cerebral protection and anti-seizure properties of propofol, while case reports indicate efficacy in the termination of seizures, particularly in status epilepticus in HDP. ${ }^{23-25}$ As most eclamptic seizures are short lived and respond quickly to magnesium sulfate, consideration should be given to the possibility of excessive sedation, prolonged postictal state, or loss of protective airway reflexes/patency if propofol or midazolam are used in a typical eclamptic seizure. If these agents are used, their administration should not supersede the $4 \mathrm{~g}$ bolus of magnesium sulfate.

\section{Volume status and fluid management}

Hemodynamic picture of untreated preeclampsia

It is widely accepted that women with preeclampsia have intravascular volume contraction (supported by low central venous pressures [CVP] and higher systemic vascular resistance than the norm for pregnancy) with high sympathetic tone and supranormal cardiac output (CO). With new technologies, such as noninvasive hemodynamic monitors and echocardiography, the notion of intravascular volume contraction in women with HDP is being challenged. ${ }^{26}$ Crozier et al. recently proposed that rightsided pressures are low as a consequence of a very effective heart and significantly increased $\mathrm{CO}^{26}$ 
Such a model could explain the poor correlation between the CVP and the pulmonary capillary wedge pressure found in preeclampsia ${ }^{11,26}$ and why CVP is not a useful measure of intravascular volume. Both SOGC and AOGC guidelines recommend against use of invasive hemodynamic monitors except for infusion of vasoactive drugs or in cases of poor peripheral vascular access. ${ }^{5,6}$ Less invasive hemodynamic monitors (e.g., arterial waveform analysis and impedance cardiography) have been investigated in preeclampsia with evidence of correlation with thermodilution-derived indices. ${ }^{27}$ Transthoracic echocardiography provides structural and functional information about cardiac function and responses to interventions. ${ }^{28,29}$

In an echocardiographic study of maternal hemodynamics, early-onset (as opposed to late-onset) preeclampsia was associated with higher total vascular resistance and lower $\mathrm{CO}$, suggesting a low filling state with pressure overload. ${ }^{30}$ While no study specifically addresses the differences between the two subtypes in response to labour and neuraxial anesthesia, more exaggerated alteration of cardiovascular physiology and a propensity towards multi-organ dysfunction are seen in early-onset preeclampsia.

\section{Intravascular volume management, pulmonary edema and renal failure}

Women with preeclampsia are prone to develop interstitial edema, and $3 \%$ of cases may develop pulmonary edema, which is associated with significant mortality and morbidity. ${ }^{31}$ Restrictive fluid policy in patients with HDP is widely accepted and has led to the reduction in pulmonary edema. ${ }^{5,6,11}$ Therefore, plasma volume expansion using either crystalloid or colloid solutions is not recommended for women with preeclampsia., ${ }^{5,6,11}$ Intravenous and oral intake should be minimized and monitored. In the absence of preexisting renal disease or a rising serum creatinine, oliguria at $<15 \mathrm{~mL} \cdot \mathrm{hr}^{-1}$ can be tolerated for six consecutive hours without significant harm. Furosemide should be reserved for the treatment of pulmonary edema. ${ }^{5,6}$

Progressive renal insufficiency in HDP is defined as creatinine of $>150 \mathrm{mg} \cdot \mathrm{dL}^{-1}$ or doubling of serum creatinine in the absence of other preexisting renal disease and is considered a maternal indication for delivery. ${ }^{5,6,11}$ Between 2003 and 2010, the rates of obstetric acute renal failure increased significantly in Canada amongst women with HDP, particularly amongst those with significant proteinuria. ${ }^{32}$ Some of the proposed contributing factors were inappropriate fluid management, drug interactions (antihypertensives, nonsteroidal antiinflammatories, statins), and postpartum hemorrhage.

\section{Role and management of labour analgesia}

Epidural labour analgesia is strongly recommended in women with preeclampsia. ${ }^{5,6,11}$ In the absence of usual contraindications (most notably coagulopathy), epidural analgesia has been safe and effective in attenuating sympathetic response to labour pain, decreasing oxygen consumption, as well as providing a safe and expeditious mode of neuraxial anesthesia in the event of operative delivery. ${ }^{33}$ Therefore, consideration of early epidural catheter placement should occur prior to a potential platelet decrease with advancing disease. This is an important element of the strategy to avoid general anesthesia in this patient population. The timing of epidural catheter removal postpartum should also be carefully considered, as these events are potentially disruptive to the paraspinal vessels. Where epidural analgesia is not possible, parenteral narcotics are recommended as an alternative. ${ }^{5,6}$

Excessive platelet activation due to endothelial dysfunction is one of the hallmarks of the pathophysiological model of preeclampsia. ${ }^{9}$ This leads to an increase in platelet sequestration and a decrease in circulating platelet counts. The degree of thrombocytopenia in preeclampsia depends on the disease severity and whether placental abruption is present. ${ }^{11}$ Spinal and epidural hematomas are rare but well-known complications of neuraxial anesthesia in women with impaired hemostasis. The overall incidence of paraspinal bleeding associated with neuraxial techniques is lower in the obstetric population than in the non-obstetric population. ${ }^{27,33}$

For parturients with preeclampsia, measuring the platelet count is recommended upon admission to the labour unit. ${ }^{5,6,11}$ The exact platelet count that is "safe" for neuraxial instrumentation is controversial. Thromboelastography of blood samples of women with preeclampsia found no impairment of coagulation at platelet counts of greater than $75 \times 10^{-9} \cdot \mathrm{L}^{-1} \cdot{ }^{33}$ In the absence of thrombocytopenia below $100 \times 10^{-9} \cdot \mathrm{L}^{-1}$ and without clinical findings of hemorrhage, no further laboratory evaluation of hemostasis should be neccesary. ${ }^{27}$ Given the potential for rapid deterioration in patients with preeclampsia, if the count falls below $100 \times 10^{-9} \cdot \mathrm{L}^{-1}$, serial measurement of platelet counts should be performed and coagulation indices and fibrinogen levels should be determined. ${ }^{27}$

Corticosteroid treatment can improve platelet count and biochemical indices; however, while frequently administered for fetal lung maturity, it is not currently recommended for the treatment of HELLP syndrome. ${ }^{6}$ Platelet transfusion is recommended in the event of severe thrombocytopenia of $<49 \times 10^{-9} \cdot \mathrm{L}^{-1}$ in the setting of Cesarean delivery, and when $<20 \times 10^{-9} \cdot \mathrm{L}^{-1}$ regardless 
of the mode of delivery. ${ }^{6}$ Clinical bleeding warrants detailed assessment of hemostasis given the high prevalence of DIC and subsequent hypofibrinogenemia. In our practice, direct arterial pressure measurement with radial (or other) artery cannulation facilitates hemodynamic monitoring and blood sampling, allowing frequent reassessment in parturients with severe derangement of hepatic function and hemostasis.

In each actual case, anesthesiologists should carefully weigh the risk of a rare but potentially devastating complication of spinal hematoma against the many benefits of neuraxial anesthesia in the preeclamptic patient.

\section{Anesthesia for operative delivery}

It is generally accepted that difficult and failed intubation is more common amongst women with HDP. ${ }^{15}$ In addition, the stimulus of laryngoscopy carries the risk of triggering a hypertensive crisis and cerebrovascular insult. Unless contraindicated, neuraxial anesthesia is preferred in a preeclamptic woman. Spinal anesthesia is preferred over de novo epidural for surgical anesthesia due to the speed of onset and a less traumatizing needle calibre. Post-spinal hypotension is less common and less severe in preeclamptic women than in their healthy counterparts. ${ }^{27}$

If general anesthesia is selected due to urgency or existing contraindications, it is imperative to predict and control the hypertensive response to laryngoscopy. ${ }^{5}$ There is insufficient evidence to recommend a single specific agent for prevention of hypertensive response during laryngoscopy, but esmolol, nitroglycerine and labetalol (for non-urgent cases) have been associated with good results. Lidocaine and magnesium sulphate boluses are currently not recommended for prevention of hypertensive response to laryngoscopy in women with HDP. ${ }^{5,6}$ Some practitioners omit narcotics during a routine induction sequence for an obstetrical general anesthesia; however, in the setting of severe preeclampsia, a neuroprotective induction may justify intravenous narcotic despite the risk of neonatal depression. While not specifically addressed by any of the guidelines, remifentanil at doses of $>1 \mu \mathrm{g} \cdot \mathrm{kg}^{-1}$ was found reliable in attenuating the response to laryngoscopy while producing hypotension in only a small number of cases. ${ }^{34,35}$

The hemodynamic response to vasopressors in these patients may be exaggerated, and hypotension should be easily corrected using small incremental doses of phenylephrine or ephedrine without adverse fetal effects. ${ }^{5,27}$ The safety and neonatal consequences of prophylactic phenylephrine infusion, now part of routine prevention of post-spinal hypotension, have not been assessed in preeclamptic women. $^{11,27}$ The SOGC guidelines recommend against routine volume loading when initiating neuraxial blockade in patients with preeclampsia. We were not able to find any study examining fluid management in preeclamptic women receiving neuraxial anesthesia or analgesia. Nevertheless, the strategy of restrictive fluid management seems to be based on the failure of fluid pre/ co-loading to prevent post-spinal hypotension and the brevity of its effect on central filling pressures in contrast with an increased incidence of pulmonary edema when liberal fluid administration is allowed. ${ }^{6,23,25}$

\section{Anesthetic issues in the postpartum period}

A significant number of parturients with antenatal hypertension will remain hypertensive postpartum, occasionally requiring initiation of antihypertensive therapy in the puerperium. Those who develop de novo hypertension postpartum may present with end-organ dysfunction as late as three weeks postpartum. ${ }^{5,6}$ There is no consensus regarding the choice of postpartum antihypertensive agent as many, including some angiotensin inhibitors, are acceptable during breastfeeding.

The SOGC guidelines recommend against prescribing nonsteroidal anti-inflammatory drugs (NSAID) in patients with worsening hypertension, high creatinine levels, and thrombocytopenia. A retrospective review published since these guidelines found no adverse effect associated with the use of postpartum NSAIDs in patients with severe hypertensive disorders of pregnancy. ${ }^{36}$ In our view, optimal postpartum analgesia has a role in minimizing postpartum hypertension; however, prescribing should be carefully considered in patients who display more significant renal involvement or disease severity. In patients with evidence of ongoing renal injury or thrombocytopenia, NSAID analgesia should be withheld until resolution of any end-organ dysfunction is confirmed.

Even when women with a history of HDP are normotensive in the postpartum period, further assessment and long-term follow-up is warranted as they may benefit from an assessment of the traditional markers of cardiovascular risk. These women should be informed of an increased long-term risk of hypertension, cardiovascular and cerebrovascular morbidity, mortality, renal disease, thromboembolism, hypothyroidism, and type 2 diabetes. $5,6,37$

There is growing evidence that women may experience post-traumatic stress disorder (PTSD) for years postpartum, especially after prolonged maternal hospitalization. Healthcare workers should be alert to symptoms of PTSD and provide timely referral for evaluation and treatment. ${ }^{5,6}$ 


\section{Summary}

Hypertensive diseases in pregnancy are on the rise in Canada and worldwide, and this trend is expected to continue into the future. Anesthesiologists have become an integral part of the multidisciplinary teams that manage hypertensive pregnant patients. The latest iteration of the SOGC clinical guidelines addresses many aspects of anesthetic care in preeclampsia. Furthermore, it proposes new classifications and new diagnostic criteria that aim to predict disease progression and ensure timely and appropriate treatment.

While our expertise is typically sought for the treatment of acute and severe hypertension, fluid management, labour analgesia, anesthesia for operative delivery, and maternal organ support, understanding the disease process and acquiring knowledge of the guidelines governing current obstetrical care are essential to quality care for patients with this potentially life-threatening condition.

\section{Clinical Case}

You are consulted to provide anesthesia for Cesarean delivery for a 24-yr-old G1P0 woman at 32 weeks' gestation. Before her pregnancy, the patient had no previous blood pressure (BP) concerns. She had one episode of hypertension at 26 weeks that was diagnosed as transient hypertension. In the past $24 \mathrm{hr}$, however, her BP has been elevated (150/100), and she received a single dose of oral labetalol $200 \mathrm{mg}$ and corticosteroids. She has just been admitted to your birth unit and now has headache, nausea, right upper quadrant pain, and elevated liver function tests (LFTs). Today, ultrasound fetal surveillance reveals restriction of intrauterine growth and absent end-diastolic flow in the umbilical artery. Your obstetrical colleague reports that the patient has an unfavourable cervix and requires urgent Cesarean delivery. She has been fasting four hours, and recently received two doses of intravenous labetalol.

Her present vitals include BP 164/102 $\mathrm{mmHg}$, heart rate 90 beats $\min ^{-1}$, normal sinus rhythm, $\mathrm{SpO}_{2} 96 \%$, and fetal heart rate 130 beats $\mathrm{min}^{-1}$. Her body mass index is 36 $\mathrm{kg} \cdot \mathrm{m}^{-2}$.

The airway exam is favourable, showing a Mallampati view 2 , mouth opening $>4 \mathrm{~cm}$, thyromental distance $>6$ $\mathrm{cm}$, and good mandibular advancement.

A complete blood count two hours ago revealed hemoglobin $128 \mathrm{~g} \cdot \mathrm{L}^{-1}$, platelets $68 \times 10^{-9} \cdot \mathrm{L}^{-1}$, and stable elevated LFTs: aspartate aminotransferase (AST) 130, alanine aminotransferase (ALT) 90, and lactate dehydrogenase (LDH) 500.
Instructions for completing the continuing professional development (CPD) module:

1. Read the current article and the references indicated in bold.

2. Go to: http://www.cas.ca/Members/CPD-Online and select the current module: Hypertensive disorders of pregnancy.

3. Answer the multiple choice questions regarding the case scenario.

4. Once you have entered all of your answers, you will have access to experts' explanations for all the possible choices.

5. Participants may claim up to four hours of CPD for a total of 12 credits under Section 3 of the CPD program of the Royal College of Physicians and Surgeons of Canada.

\section{Les troubles hypertensifs de la grossesse}

\begin{abstract}
Résumé
Objectif Dans ce module de développement professionnel continu, nous examinons la directive récente de la Société des obstétriciens et gynécologues du Canada (SOGC) concernant la classification et le diagnostic des troubles hypertensifs de la grossesse (THG) ainsi que les caractéristiques cliniques, les examens de laboratoire et les issues des THG. Nous examinons les données probantes concernant la prise en charge anesthésique et la prévention des atteintes des organes cibles chez les femmes atteintes de THG et décrivons le rôle et la contribution des anesthésiologistes dans le cadre d'une équipe de soins multidisciplinaire.
\end{abstract}

Constatations principales Les troubles hypertensifs de la grossesse peuvent se présenter sous différentes formes et les signes et symptômes cliniques n'ont fréquemment pas de corrélation à la gravité et à la progression sous-jacentes de la maladie. Si le diagnostic et le traitement ne sont pas entrepris au moment opportun, ils deviennent des facteurs contribuant significativement aux complications maternelles (complications neurologiques, œdème pulmonaire et hémorragie postpartum) et néonatales (complications respiratoires et neurologiques et mortinaissance). Dans le contexte canadien, les progrès en matière de soins médicaux ont abouti à de meilleures issues maternelles et néonatales. La chronologie de l'accouchement est cruciale pour équilibrer les risques encourus par la mère et les bienfaits, pour le fotus, de poursuivre la grossesse. La directive clinique de la SOGC concernant le diagnostic et la prise en charge des THG aborde de nombreux aspects des soins cliniques pertinents 
pour l'anesthésiologiste, lequel joue un rôle important dans l'équipe de soins multidisciplinaire.

Conclusion Les THG sont de plus en plus fréquents partout dans le monde, et on s'attend à ce que cette tendance se maintienne. Les facteurs principaux contribuant à la mortalité maternelle sont la reconnaissance tardive des THG et un délai prolongé avant de traiter adéquatement cette condition. Il est essentiel que les anesthésiologistes comprennent le processus de la maladie et soient au courant des directives régissant les soins obstétricaux, afin de procurer des soins multidisciplinaires de qualité et fondés sur des données probantes à ces patientes. La prise en charge anesthésique aide à prévenir des issues maternelles et fœtales potentiellement dévastatrices.

\section{Objectifs de ce module de développement professionnel continu (DPC):}

Après avoir lu ce module, le lecteur devrait être en mesure de:

1. Décrire la directive pratique récente de la Société des obstétriciens et gynécologues du Canada (SOGC) concernant le diagnostic et la classification des troubles hypertensifs de la grossesse (THG), y compris les caractéristiques cliniques et les tests de laboratoire.

2. Identifier les principales complications maternelles et fotales de la grossesse qui sont causées par les THG.

3. Mettre au point une approche factuelle quand à la prise en charge pharmacologique de l'hypertension et la prévention des atteintes des organes cibles chez une femme présentant une prééclampsie.

4. Décrire le rôle de l'anesthésiologiste dans la prise en charge multidisciplinaire des THG.

5. Passer en revue les objectifs de la prise en charge anesthésique et les réponses cardiovasculaires à l'anesthésie générale, l'analgésie/anesthésie neuraxiale, les vasopresseurs et les utérotoniques chez les femmes atteintes de THG.

6. Décrire l'évaluation et la préparation d'une parturiente devant subir un accouchement par césarienne urgent sous anesthésie générale en énumérant les considérations anesthésiques, obstétricales et fotales.

7. Décrire les besoins postpartum des femmes présentant une prééclampsie.

\section{Vue d'ensemble et incidence}

Les troubles hypertensifs de la grossesse (THG) peuvent avoir une symptomatologie à plusieurs facettes dont la gravité peut aller d'un trouble bénin qui se manifeste au cours du troisième trimestre à un trouble multisystémique explosif qui apparaît de façon précoce $(<34$ semaines de gestation) et évolue rapidement jusqu'à un dysfonctionnement grave des organes cibles chez la mère et à un danger pour le fotus.

Dans le monde, les THG affectent 3-8 \% des grossesses et contribuent de façon significative à la morbidité et à la mortalité maternelle et néonatale. ${ }^{1}$ Au Canada, les taux de THG demeurent relativement stables depuis une dizaine d'années (environ $5 \%)^{2,3}$ L'hypertension sans protéinurie, tout comme l'hypertension préexistante, sont devenues plus fréquentes, particulièrement chez les femmes d'âge maternel avancé. ${ }^{2}$ Entre 2002 et 2011, 34 parturientes sont décédées au Canada des suites d'une hypertension et de troubles associés, et on estime qu'il y a eu environ 50 cas évités de justesse au cours de la même période. ${ }^{4}$ Étant donné la prévalence croissante des facteurs de risque dans la population obstétricale (par ex. un âge maternel avancé, l'obésité, l'hypertension et le diabète), les taux de THG vont vraisemblablement augmenter à l'avenir. Les facteurs de risque les plus importants de prééclampsie sont: 1) un syndrome des antiphospholipides, 2) une prééclampsie précédente, 3) un diabète de type 1,4 ) une grossesse multiple, 5) la nulliparité, 6) des antécédents familiaux de prééclampsie, 7) l'obésité, 8) un âge $>40$ ans, et 9) une hypertension préexistante..$^{5-7}$

Les THG constituent un énorme fardeau pour la femme touchée, pour sa famille, et pour la société. Au niveau mondial, les nourrissons de mères prééclamptiques courent un risque accru de convulsions, d'encéphalopathie néonatale, d'admission aux soins intensifs, ainsi qu'un risque doublé de mortalité périnatale. ${ }^{8}$ Au Canada, les taux de morbidité et de mortalité maternelles sont demeurés stables malgré une incidence accrue de THG, ce qui indique probablement une meilleure efficacité des soins médicaux. ${ }^{3}$ Le recours de plus en plus fréquent à des interventions thérapeutiques a également considérablement réduit le taux de morbidité et de mortalité fœtale et infantile. ${ }^{3}$

\section{Physiopathologie}

On a proposé un modèle à deux stades de la physiopathologie de la prééclampsie, qui associe une perfusion placentaire inadéquate (premier stade) à l'apparition subséquente d'un dysfonctionnement endothélial maternel (deuxième stade), qui à son tour provoque les manifestations cliniques de la prééclampsie. Le premier stade peut être déclenché par des conditions maternelles préexistantes (par ex. une maladie microvasculaire causée par un diabète chronique ou de l'hypertension), une placentation anormale entravant le remodelage vasculaire, ou une condition obstétricale de demande placentaire accrue (par ex. une grossesse multiple). ${ }^{9}$ 
La placentation, lorsqu'elle est normale, se caractérise par une invasion trophoblastique dans les artères spiralées de l'utérus, ce qui résulte en une diminution de la résistance vasculaire, une perte des muscles lisses artériolaires et une dilatation des vaisseaux terminaux - cette interaction des tissus maternels et fotaux fait appel à des mécanismes immunologiques complexes. L'effet de ces changements est une augmentation du volume de l'espace intervilleux et une réduction de la vélocité du sang. Lorsque la placentation ne se fait pas normalement, on assiste à une réduction du volume et une augmentation de la vélocité du sang placentaire, ce qui provoque une hypoxie placentaire, un stress oxydatif et des lésions vasculaires mécaniques. Les syncytiotrophoblastes réagissent à ces conditions en activant des cascades d'inflammation et de coagulation, et libèrent une kyrielle de médiateurs en aval, notamment des protéines anti-angiogéniques (Fig. 1, page 3).

Lorsqu'elle survient de façon isolée, la dysfonction placentaire ne suffit pas à provoquer un syndrome d'activation des cellules endothéliales maternelles. Des recherches reliant les deux stades ont identifié plusieurs biomarqueurs et cibles qui pourraient potentiellement faciliter le diagnostic, le traitement et la prévention (par ex., le facteur de croissance placentaire et la tyrosinekinase 1 - fms soluble); leur utilisation clinique est en cours d'étude. Malgré une meilleure compréhension du rôle de ces biomarqueurs dans les cas de prééclampsie, les données factuelles ne sont pas encore suffisantes pour recommander leur utilisation de routine dans la pratique clinique.,

Le moment où apparaît l'hypertension pendant la grossesse pourrait être étroitement lié à sa physiopathologie sous-jacente. Traditionnellement, une prééclampsie est considérée d'apparition précoce si elle se manifeste avant 34 semaines de gestation, alors que si elle apparaît plus tard, elle sera décrite comme une prééclampsie d'apparition tardive. La maladie précoce, plus agressive, est plus souvent associée à un développement placentaire anormal ainsi qu'à un retard de croissance intra-utérin. En revanche, on pense que la prééclampsie d'apparition tardive (c.-à-d. après 34 semaines de gestation) survient à la suite d'une maladie microvasculaire maternelle (telles que l'hypertension chronique ou le diabète) ou à une disposition génétique de la mère; elle est souvent associée à une croissance fotale quasi normale. ${ }^{10}$

\section{Classification et critères diagnostiques}

Directives de pratique clinique

D'importants organismes professionnels nationaux en Amérique du Nord et en Europe, notamment l'American College of Obstetricians and Gynecologists (ACOG), ${ }^{11}$ la
Société des obstétriciens et gynécologues du Canada (SOGC), ${ }^{5,6}$ et le National Institute for Health and Care Excellence (Royaume-Uni) ont publié des critères diagnostiques et des directives de prise en charge. ${ }^{12}$ Alors que les experts s'accordent généralement quant à la classification de l'hypertension de grossesse, certains points demeurent controversés, notamment la nécessité d'une protéinurie dans le diagnostic de la prééclampsie, les valeurs limites pour amorcer un traitement anti-hypertensif, ainsi que la recommandation d'administrer du sulfate de magnésium en prophylaxie contre les convulsions.

La Directive clinique de la SOGC a été publiée pour la première fois en 2008 puis mise à jour en 2014. Fait à souligner, le terme «hypertension induite par la grossesse » n'est plus utilisé dans la version de 2014. Les THG sont dorénavant classés en hypertension préexistante, hypertension gestationnelle, prééclampsie, ou " autres effets hypertensifs », en fonction de divers facteurs diagnostiques et thérapeutiques. ${ }^{5,6}$ La catégorie « autres effets hypertensifs », qui inclut l'hypertension circonstancielle ou 'de la blouse blanche', a été ajoutée pour souligner que les patientes qui manifestent une hypertension dans un environnement médical courent tout de même un risque considérablement plus élevé de manifester une hypertension gestationnelle, voir une prééclampsie (Tableau 1 - adapté de Magee et coll.). ${ }^{5,6}$

\section{Critères diagnostiques}

Le diagnostic de l'hypertension demeure inchangé depuis la directive précédente. On définit l'hypertension comme une tension artérielle systolique (TAs) $\geq 140 \mathrm{mmHg}$ et/ou une tension artérielle diastolique (TAd) $\geq 90 \mathrm{mmHg}$, en se fondant sur la moyenne de deux mesures, prises à $15 \mathrm{~min}$ d'intervalle au même bras. Après une période de repos, si l'hypertension n'est pas confirmée au cours de la prise d'une deuxième mesure, elle est alors définie comme une hypertension transitoire. Une hypertension modérée est confirmée lorsque la TAs $\geq 150-159 \mathrm{mmHg}$ ou la TAd 100-109 mmHg, et une hypertension grave est confirmée lorsque la TAs $\geq 160 \mathrm{mmHg}$ ou la TAd $\geq 110 \mathrm{mmHg}$. ${ }^{5,6}$

Lorsqu'un diagnostic d'hypertension est posé pendant la grossesse, la présence de prééclampsie doit être déterminée dans les plus brefs délais. En effet, la prééclampsie constitue une sous-catégorie associée à des issues maternelles et périnatales aggravées. La prééclampsie peut se manifester de novo, ou elle peut se superposer à une hypertension préexistante ou à une hypertension gestationnelle. La protéinurie n'est plus une exigence absolue pour poser un diagnostic de prééclampsie. La mesure de la protéinurie manque de sensibilité (bandelette réactive urinaire) et s'accompagne de problèmes quant à sa rapidité et à son aspect pratique (recueil des urines de $24 \mathrm{~h}$ 
Tableau 1 Classification des THG - adapté de Magee et coll.5,6

Hypertension préexistante

- En présence de comorbidité(s)

- En présence de symptômes de prééclampsie

Hypertension gestationnelle

- En présence de comorbidité(s)

- En présence de symptômes de prééclampsie

Prééclampsie

Autres effets hypertensifs

- Effet hypertensif transitoire

- Effet hypertensif circonstanciel (de la blouse blanche)

- Effet hypertensif masqué
L'hypertension était présente avant la grossesse ou est apparue à $<20$ semaines de gestation

La présence de comorbidités (par ex. diabète sucré prégestationnel de type I ou II ou néphropathie) justifie la mise en œuvre d'une surveillance plus étroite de la TA en l'absence de grossesse, en raison de leur association avec une accentuation du risque cardiovasculaire

Cette situation est également connue sous le nom de «prééclampsie surajoutée » et est définie par l'apparition d'au moins un des éléments suivants à $\geq 20$ semaines:

- hypertension réfractaire, ou

- protéinurie récente ou en recrudescence, ou

- au moins un état indésirable, ou

- au moins une complication grave

Définie comme étant une hypertension qui se manifeste pour la première fois à $\geq 20$ semaines de gestation

La présence de comorbidités (par ex. diabète sucré prégestationnel de type I ou II ou néphropathie) justifie la mise en œuvre d'une surveillance plus étroite de la TA en l'absence de grossesse, en raison de leur association avec une accentuation du risque cardiovasculaire

Les symptômes de prééclampsie pourraient ne se manifester que plusieurs semaines après l'apparition d'une hypertension gestationnelle.

La prééclampsie est définie comme une hypertension gestationnelle s'accompagnant d'au moins un des éléments suivants:

- protéinurie récente, ou

- au moins un état indésirable, ou

- au moins une complication grave

La prééclampsie pourrait se manifester de novo.

Elle est définie comme une hypertension gestationnelle s'accompagnant d'au moins un des éléments suivants:

- protéinurie récente, ou

- au moins un état indésirable, ou

- au moins une complication grave

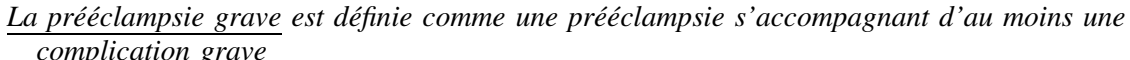

La hausse de la TA pourrait être attribuable à des stimuli environnementaux ou la douleur du travail, par exemple

Défini comme une TA qui s'avère élevée lorsqu'elle est mesurée en cabinet (TAs $\geq 140 \mathrm{mmHg}$ ou TAd $\geq 90 \mathrm{mmHg})$ mais qui s'avère régulièrement normale $(<135 / 85 \mathrm{mmHg})$ hors du cabinet

Défini comme une TA qui s'avère régulièrement normale lorsqu'elle est mesurée en cabinet (TAs < $140 \mathrm{mmHg}$ ou TAd $<90 \mathrm{mmHg})$ mais qui s'avère élevée $(\geq 135 / 85 \mathrm{mmHg})$ hors du cabinet

$\mathrm{TA}=$ tension artérielle; $\mathrm{TAd}=$ tension artérielle diastolique; $\mathrm{TAs}=$ tension artérielle systolique; $\mathrm{THG}=$ troubles hypertensifs de la grossesse

pour les protéines dans l'urine, ce qui retarde le traitement). De plus, la gravité de la protéinurie ne constitue pas un prédicteur de la gravité ou de l'issue de la maladie. Au lieu de cela, étant donné nos connaissances actuelles concernant la nature multisystémique de la maladie, si une prééclampsie est soupçonnée, même sans protéinurie, une évaluation urgente des signes de dysfonction d'organes cibles ou de « caractéristiques graves » (par ex. maux de tête ou dysfonction rénale) est recommandée (Tableau 2).

En cas d'hémolyse, de taux élevé d'enzymes hépatiques et de thrombopénie chez une patiente enceinte, il est probable qu'un syndrome HELLP (pour 'hemolysis, $\boldsymbol{e}$ levation of $\boldsymbol{l}$ iver enzyme, et $\boldsymbol{l o w}$ platelets') soit présent.
Bien que très souvent manifestes en présence d'autres troubles hypertensifs de la grossesse, la protéinurie et l'hypertension pourraient être absentes. Plusieurs autres conditions médicales sont accompagnées de caractéristiques semblables et peuvent imiter la présentation d'un syndrome HELLP, par exemple une stéatose hépatique de grossesse ou un purpura thrombopénique idiopathique. ${ }^{13}$

\section{Stratification des risques et prédicteurs de l'issue}

Chez les patientes atteintes de THG, le risque d'issues maternelles ou périnatales néfastes est augmenté 
Tableau 2 États indésirables et complications graves de la prééclampsie - adapté de Magee et coll., ${ }^{5,6}$

\begin{tabular}{|c|c|c|}
\hline $\begin{array}{l}\text { Système } \\
\text { organique affecté }\end{array}$ & $\begin{array}{l}\text { États indésirables (qui entraînent la hausse } \\
\text { du risque de complications graves) }\end{array}$ & $\begin{array}{l}\text { Complications graves } \\
\text { (qui justifient la tenue de l'accouchement) }\end{array}$ \\
\hline SNC & - Maux de tête / symptômes visuels & $\begin{array}{l}\text { - Éclampsie } \\
\text { - PRES (syndrome d'encéphalopathie postérieure réversible) } \\
\text { - Cécité corticale ou décollement rétinien } \\
\text { - Échelle de coma de Glasgow }<13 \\
\text { - AVC, AIT ou RIND }\end{array}$ \\
\hline Cardiorespiratoire & $\begin{array}{l}\text { - Douleur thoracique / dyspnée } \\
\text { - Saturation en oxygène < }<97 \%\end{array}$ & $\begin{array}{l}\text { - Hypertension grave non maîtrisée (sur une période de } 12 \mathrm{~h} \text {, malgré } \\
\text { l'utilisation de trois antihypertenseurs) } \\
\text { - Saturation en oxygène }<90 \% \text {, nécessité d'avoir recours à } \geq 50 \% \text { d'oxygène } \\
\text { pendant }>1 \mathrm{~h} \text {, intubation (pour des raisons autres que la tenue d'une } \\
\text { césarienne), œdème pulmonaire } \\
\text { - Soutien inotrope positif } \\
\text { - Ischémie ou infarctus du myocarde }\end{array}$ \\
\hline Hématologique & $\begin{array}{l}\text { - Hausse de la leucocytémie } \\
\text { - Hausse du RIN ou du TCA } \\
\text { - Faible numération plaquettaire }\end{array}$ & $\begin{array}{l}\text { - Numération plaquettaire }<50 \times 10^{-9} \cdot \mathrm{L}^{-1} \\
\text { - Transfusion de tout produit sanguin }\end{array}$ \\
\hline Rénal & $\begin{array}{l}\text { - Hausse du taux sérique de créatinine } \\
\text { - Hausse du taux sérique d'acide urique }\end{array}$ & $\begin{array}{l}\text { - Atteinte rénale aiguë (créatinine }>150 \mu \mathrm{Mol} \cdot \mathrm{L}^{-1} \text { sans antécédents de } \\
\text { néphropathie) } \\
\text { - Nouvelle indication pour dialyse }\end{array}$ \\
\hline Hépatique & $\begin{array}{l}\text { - Nausée ou vomissements } \\
\text { - Douleur épigastrique ou au QSD } \\
\text { - Hausse des taux sériques d'ASAT, } \\
\text { d'ALAT, de LDH ou de bilirubine } \\
\text { - Faible taux plasmatique d'albumine }\end{array}$ & $\begin{array}{l}\text { - Dysfonctionnement hépatique (RIN }>2 \text { en l'absence de CIVD ou de } \\
\text { warfarine) } \\
\text { - Hématome ou rupture hépatique }\end{array}$ \\
\hline Fœto-placentaire & $\begin{array}{l}\text { - FCF anormale } \\
\text { - RCIU } \\
\text { - Oligohydramnios } \\
\text { - Absence ou inversion du débit en fin de } \\
\text { diastole }\end{array}$ & $\begin{array}{l}\text { - Décollement placentaire s'accompagnant de symptômes indiquant un danger } \\
\text { grave pour la mère ou le fœtus } \\
\text { - Négativité de l'onde alpha du ductus venosus } \\
\text { - Mortinaissance }\end{array}$ \\
\hline
\end{tabular}

AIT = accident ischémique transitoire; ALAT = alamine aminotransférase; ASAT = aspartate aminotransférase; CIVD = coagulation intravasculaire disséminée; $\mathrm{FCF}=$ fréquence cardiaque fotale; $\mathrm{LDH}=$ lacticodéshydrogénase; $\mathrm{QSD}$ : quadrant supérieur droit; RCIU = retard de croissance intra-utérin; RIN = rapport international normalisé; RIND = accident ischémique cérébral régressif; SNC = système nerveux central; TCA = temps de céphaline activé

lorsqu'une prééclampsie précoce $(<34$ semaines de gestation) ou quand certaines conditions maternelles aggravantes apparaissent en raison d'un dysfonctionnement endothélial diffus (Tableau 2). ${ }^{5,6}$ Parmi ces conditions, citons les maux de tête, les douleurs thoraciques ou la dyspnée, une réduction de la saturation en oxygène, une thrombopénie, des taux élevés de créatinine ou d'aspartate aminotransférase (ASAT).

Les patientes qui présentent un syndrome HELLP courent un risque élevé de complications graves, telles qu'un décollement placentaire (16\%), une coagulation intravasculaire disséminée (CIVD) $(20 \%)$ et une insuffisance rénale aiguë $(8 \%){ }^{13}$ La mortalité maternelle rapportée est de $1 \%$ et la mortalité néonatale peut atteindre $34 \%$ lorsque le nouveau-né est mis au monde avant 34 semaines de gestation. ${ }^{14}$ L'état des patientes atteintes d'un syndrome HELLP peut s'aggraver rapidement et leur rétablissement peut être retardé; en outre, les symptômes augmentent souvent après l'accouchement.

\section{La prise en charge obstétricale}

Lieu des soins et voies d'accès

Bien que les patientes atteintes d'hypertension grave ou de prééclampsie grave devraient être hospitalisées, l'alitement ne semble pas avoir d'impact sur la gravité de la maladie et n'est pas recommandé. 5,6 
Mode d'accouchement

L'accouchement vaginal est toujours souhaitable, et l'accouchement par césarienne devrait être envisagé pour les indications obstétricales et néonatales usuelles. ${ }^{5,6}$ L'approche intrapartum et postpartum recommandée comprend la prise en charge active du troisième stade de travail (administration parentérale d'oxytocine), le maintien du traitement antihypertensif tout au long du travail obstétrical et de l'accouchement, et éviter l'ergométrine pour le traitement de l'atonie utérine.

\section{Chronologie de l'accouchement}

L'accouchement du placenta est la seule intervention définitive menant à la résolution de la prééclampsie; par conséquent, la décision d'accoucher se fonde sur l'évaluation des risques maternels et fotaux de poursuivre la grossesse, par rapport aux risques néonataux d'un accouchement immédiat. ${ }^{15}$ Parmi les indications consensuelles qui justifient un accouchement immédiat, on compte une grossesse à terme, l'apparition de graves complications maternelles associées aux THG, une mortinaissance, ou un monitorage fotal indiquant qu'un accouchement est indiqué, selon les règles de la pratique obstétricale générale. ${ }^{5,6}$ Chez les femmes qui présentent une prééclampsie à terme (> 37 semaines de gestation), l'accouchement immédiat est fortement recommandé. ${ }^{16}$ Toutes les femmes qui présentent une prééclampsie grave devraient être accouchées immédiatement, sans égard à l'âge gestationnel. La tenue immédiate de l'accouchement devrait être envisagée chez toutes les femmes qui présentent un syndrome HELLP après 35 semaines de grossesse. Entre 24 et $34^{+6}$ semaines de grossesse, l'accouchement devrait être retardé jusqu'à l'administration de corticostéroïdes prénataux. $^{5}$

Une prise en charge non interventionniste (c.-à-d. laisser la grossesse se poursuivre) pourrait être bénéfique pour les patientes présentant une prééclampsie non-grave à $24-33^{+6}$ semaines. Selon de nouvelles données probantes, tirées de l'étude HYPITAT-II ("Immediate delivery versus expectant monitoring for hypertensive disorders of pregnancy between 34 and 37 weeks of gestation", soit "Accouchement immédiat versus monitorage non interventionniste pour les troubles hypertensifs de la grossesse entre 34 et 37 semaines de grossesse') réalisée en 2015 et publiée après la Directive de la SOGC, l'accouchement immédiat pourrait réduire le faible risque de complications maternelles mais, dans le groupe non interventionniste, la prolongation de la grossesse d'aussi peu que cinq jours avait significativement réduit le risque de détresse respiratoire néonatale. ${ }^{17}$
Objectif des traitements antihypertensifs

L'objectif du traitement est de contrôler l'hypertension tout en préservant la perfusion du placenta et des organes cibles de la mère. Les directives s'accordent moins quant à la valeur où on doit traiter, et la TA cible. La directive de la SOGC recommande de traiter l'hypertension maternelle modérée à grave. La TA cible demeure controversée, l'inquiétude étant qu'une réduction trop rapide puisse entrainer des complications graves pour la mère et le fœtus. Les objectifs de traitement de la SOGC suggèrent de réduire la TAs à $130-155 \mathrm{mmHg}$, la TAd à $80-105 \mathrm{mmHg}$ chez les patientes présentant une hypertension non grave, et la TA à moins de $140 / 90 \mathrm{mmHg}$ chez les patientes présentant des comorbidités. Une hypertension grave nécessite un traitement urgent avec pour cible de réduire la TA à moins de 160/110 mmHg.

Le sulfate de magnésium

\section{Prévention des convulsions}

L'éclampsie, définie comme la survenue de crises tonicocloniques (ou de grand mal) chez les femmes enceintes présentant une prééclampsie sous-jacente, peut être la première manifestation clinique de THG. Elle est associée à une morbidité grave (par ex. insuffisance rénale, œdème pulmonaire, pneumonie par aspiration, accident vasculaire cérébral et arrêt cardiorespiratoire) et une mortalité maternelle de l'ordre de $1 \%$.

Le sulfate de magnésium est supérieur à tout autre agent pour le traitement prophylactique de l'éclampsie. Il réduit de façon significative la survenue des convulsions de plus de $50 \%$ via un mécanisme d'action probablement multifactoriel: un relâchement des muscles lisses vasculaires via les inhibiteurs calciques, provoquant une vasodilatation qui pourrait réduire la résistance vasculaire totale; une réduction de la perméabilité endothéliale cérébrale via les systèmes de messager second calcium-dépendants, réduisant ainsi l'œdème vasogénique; et, finalement, une activité anticonvulsivante en une augmentation du seuil de crise via l'inhibition du récepteur de N-méthyl-D-aspartate. ${ }^{18}$

Le nombre de sujets à traiter afin de prévenir les crises de grand mal est de 50 en cas de prééclampsie grave et de 100 en cas de prééclampsie non grave. La directive actuelle de la SOGC préconise une prophylaxie de sulfate de magnésium pour contrer l'éclampsie chez les femmes présentant une prééclampsie grave ainsi que celles présentant une prééclampsie non grave mais qui manifestent également une hypertension grave, des signes de dysfonctionnements des organes cibles, ou une numération plaquettaire $<100 \times 10^{-9} \cdot \mathrm{L}^{-1}$. La 
posologie standard de sulfate de magnésium à suivre consiste en une dose initiale de $4 \mathrm{~g}$, administrée par voie intraveineuse, suivie d'une perfusion de $1 \mathrm{~g} \cdot \mathrm{h}^{-1}$. La surveillance des taux sériques de magnésium n'est pas nécessaire si la patiente reçoit un monitorage clinique des signes de toxicité - sauf en cas d'oligurie causée par une dysfonction rénale, ce qui réduira l'excrétion de magnésium et pourrait provoquer des taux sériques potentiellement élevés. ${ }^{5,6}$

\section{Prise en charge des crises tonicocloniques}

Outre sa recommandation en tant qu'agent prophylactique, un bolus de $4 \mathrm{~g}$ de sulfate de magnésium est recommandé comme agent de première intention en cas de crise d'éclampsie. ${ }^{11}$ Chez les femmes présentant une éclampsie, une perfusion de sulfate de magnésium devrait être maintenue pendant l'accouchement et durant les $24 \mathrm{~h}$ suivant la dernière convulsion. Les benzodiazépines et la phénytoïne sont réservées aux cas dans lesquels le sulfate de magnésium est contre-indiqué ou inefficace. ${ }^{5,6}$ Les directives s'accordent pour recommander que les femmes présentant une éclampsie devraient être accouchées après la stabilisation initiale de leur état.

$\mathrm{La}$ neuroprotection néonatale est une indication relativement récente pour l'administration maternelle de sulfate de magnésium dans le cadre d'une naissance préterme imminente (au cours des prochaines $24 \mathrm{~h}$ ) à $31^{+6}$ semaines, tant que la tenue d'un accouchement d'urgence n'est pas retardée par son administration.,

\section{Prise en charge anesthésique}

\section{Principes généraux}

Une communication efficace entre les membres de l'équipe multidisciplinaire est essentielle. ${ }^{5,6}$ Une consultation précoce avec l'anesthésiologiste est recommandée pour toutes les femmes présentant une prééclampsie. ${ }^{5,6,11}$ Parmi les aspects importants des soins globaux que les anesthésiologistes procurent aux femmes atteintes de THG, citons l'analgésie pour le travail obstétrical, le contrôle de l'hypertension, les soins anesthésiques en cas d'accouchement par césarienne, la prise en charge du volume intravasculaire, l'administration de composés sanguins et le monitorage invasif.

\section{Urgences hypertensives}

L'Opinion de comité de l'ACOG, publiée en 2015, aborde spécifiquement la question du traitement de l'hypertension grave et des urgences hypertensives. ${ }^{13}$ Le taux d'hypertension systolique constitue le prédicteur le plus important de lésions cérébrales et d'infarctus: dans une série de cas, une TAs $>160 \mathrm{mmHg}$ a été observée chez plus de $95 \%$ des patientes présentant une prééclampsie grave immédiatement avant la crise. ${ }^{19}$ L'hypertension grave d'apparition brutale $(>160 / 110)$ qui persiste pour un minimum de 15 min est considérée comme une urgence hypertensive lorsqu'elle est associée à des dysfonctionnements d'organes cibles. Un monitorage fœtal et un traitement pharmacologique immédiats sont indiqués pour rétablir la TA vers des valeurs de 140-150/ 90-100 $\mathrm{mmHg}$, afin de minimiser l'exposition à une hypertension systolique grave et à une perte d'autorégulation cérébrale Tableau 3.

Par le passé, le choix initial d'agents pour traiter une hypertension grave s'est habituellement fondé sur un bloc adrénergique, avec du labétalol ou de l'hydralazine. Les directives nord-américaines ajoutent à cela un bloqueur calcique à action brève sous forme orale, soit des capsules de 5-10 mg de nifédipine, en tant qu'option supplémentaire de première ligne pour le traitement en milieu hospitalier et suggèrent qu'une réduction plus rapide de la TAs pourrait ainsi être obtenue par rapport à l'administration intraveineuse de labétalol ou d'hydralazine. ${ }^{11}$ Un second agent antihypertensif devrait être ajouté si des doses successives d'un premier agent ne parviennent pas à faire baisser la TA jusqu'aux valeurs cibles.

L'ACOG décrit trois protocoles pour le traitement des urgences hypertensives. Chaque protocole commence par un médicament initial (labétalol, hydralazine, ou nifédipine orale à action rapide) puis ajoute un deuxième et un troisième agent. Bien que les directives de l'ACOG et de la SOGC ne recommandent pas spécifiquement d'éviter la combinaison hydralazine/nifédipine, le potentiel de l'hydralazine de provoquer une hypotension maternelle plus prononcée que le labétalol est clairement énoncé. ${ }^{11}$ Selon la directive de la SOGC, une hypertension grave non contrôlée (plus de $12 \mathrm{~h}$ malgré l'utilisation de trois agents antihypertensifs) justifie la tenue immédiate de l'accouchement. ${ }^{5,6}$

Dans les cas graves d'hypertension réfractaire traités en milieu hospitalier, des perfusions de nitroprusside de sodium peuvent être utilisées comme alternative, tant que l'exposition maternelle et fœtale est limitée autant que possible afin de réduire les risques liés à la toxicité du cyanure. ${ }^{5,6,11}$ Le sulfate de magnésium, lorsqu'il est utilisé seul, ne constitue pas un antihypertensif suffisamment efficace et ne devrait pas être utilisé pour le contrôle de première intention de la TA en cas de THG. Bien que les premiers cas rapportés aient soulevé des inquiétudes face à la dépression respiratoire et au bloc neuromusculaire lors de l'administration concomitante de bloqueurs des canaux calciques et de sulfate de magnésium, des comptes rendus 
Tableau 3 Traitement urgent pour l'hypertension grave d'apparition aiguë pendant la grossesse et la période postpartum à l'aide d'un des trois antihypertenseurs de première intention - adapté de l'Opinion de comité de l'ACOG ${ }^{13}$ \begin{tabular}{lll}
\hline $\begin{array}{l}\text { Prise en charge initiale de première intention } \\
\text { avec Labétalol }\end{array}$ & $\begin{array}{l}\text { Prise en charge initiale de première intention } \\
\text { avec Hydralazine }\end{array}$ & $\begin{array}{l}\text { Prise en charge initiale de première intention } \\
\text { avec Nifédipine orale }\end{array}$
\end{tabular}

Avertir le médecin si la tension artérielle (TA) systolique mesurée est égale ou supérieure à $160 \mathrm{mmHg}$ ou si la TA diastolique mesurée est supérieure ou égale à $110 \mathrm{mmHg}$. Mettre en place une surveillance fotale si avant l'accouchement et que le fotus est viable.

- Si une hausse grave de la TA persiste pour $15 \bullet$ Si une hausse grave de la TA persiste pour 15 Si une hausse grave de la TA persiste pour 15 min ou plus, administrer du labétalol (20 mg min ou plus, administrer de l'hydralazine (5 iv sur 2 min).

- Répéter la mesure de la TA 10 min plus tard • Répéter la mesure de la TA 20 min plus tard et enregistrer les résultats.

- Si la TA systolique ou diastolique est toujours au-dessus des valeurs limites, administrer du labétalol (40 mg iv sur 2 min). Si la TA est au-dessous de la valeur limite, poursuivre la surveillance étroite de la TA.

- Si la TA systolique ou diastolique est

- Répéter la mesure de la TA 10 min plus tard et enregistrer les résultats.

- Si la TA systolique ou diastolique est toujours au-dessus des valeurs limites, administrer du labétalol (80 mg iv sur 2 min). Si la TA est au-dessous de la valeur limite, poursuivre la surveillance étroite de la TA.

- Répéter la mesure de la TA 20 min plus tard

- Si la TA systolique ou diastolique est

- Répéter la mesure de la TA 10 min plus tard et enregistrer les résultats.

- Si la TA systolique ou diastolique est toujours au-dessus des valeurs limites, administrer de l'hydralazine (10 mg iv sur 2 min). Si la TA est au-dessous de la valeur limite, poursuivre la surveillance étroite de la TA.

- Répéter la mesure de la TA 20 min plus tard et enregistrer les résultats.

Si la TA systolique ou diastolique est toujours au-dessus des valeurs limites, obtenir une consultation d'urgence avec des surspécialistes en médecine materno-fœtale, en médecine interne, en anesthésie ou en soins critiques. $\mathrm{mg}$ ou $10 \mathrm{mg}$ iv sur $2 \mathrm{~min}$ ). et enregistrer les résultats. toujours au-dessus des valeurs limites, administrer de l'hydralazine (10 mg iv sur 2 min). Si la TA est au-dessous de la valeur limite, poursuivre la surveillance étroite de la TA. et enregistrer les résultats. toujours au-dessus des valeurs limites, administrer du labétalol (20 mg iv sur 2 min). Si la TA est au-dessous de la valeur limite, poursuivre la surveillance étroite de la TA. min ou plus, administrer de la nifédipine (les capsules de $10 \mathrm{mg}$ devraient être administrées par voie orale et ne devraient pas être perforées ou administrées par voie sublinguale).

- Répéter la mesure de la TA 20 min plus tard et enregistrer les résultats.

- Si la TA systolique ou diastolique est toujours au-dessus des valeurs limites, administrer des capsules de nifédipine (20 mg en administration orale). Si la TA est au-dessous de la valeur limite, poursuivre la surveillance étroite de la TA.

- Répéter la mesure de la TA 20 min plus tard et enregistrer les résultats.

- Si la TA systolique ou diastolique est toujours au-dessus des valeurs limites, administrer des capsules de nifédipine (20 mg en administration orale). Si la TA est au-dessous de la valeur limite, poursuivre la surveillance étroite de la TA.

- Si la TA systolique ou diastolique est toujours au-dessus des valeurs limites, administrer du labétalol (40 mg $i v$ sur $2 \mathrm{~min}$ ) et obtenir une consultation d'urgence avec des surspécialistes en médecine materno-fœtale, en médecine interne, en anesthésie ou en soins critiques.
- Répéter la mesure de la TA 20 min plus tard et enregistrer les résultats.

Si la TA systolique ou diastolique est toujours au-dessus des valeurs limites, administrer du labétalol (40 $\mathrm{mg} i v$ sur $2 \mathrm{~min}$ ) et obtenir une consultation d'urgence avec des surspécialistes en médecine materno-fœtale, en médecine interne, en anesthésie ou en soins critiques.

Une fois les valeurs limites de TA mentionnées ci-dessus atteintes, répéter la mesure de la TA toutes les dix minutes pendant une heure, puis toutes les 15 min pendant une heure, puis toutes les 30 minutes pendant une heure, puis toutes les heures pendant quatre heures

ACOG = American College of Obstetricians and Gynecologists

plus récents laissent penser que ces inquiétudes ne sont pas justifiées et qu'une administration concomitante de ces agents est sécuritaire en milieu hospitalier. ${ }^{6,20-22}$

\section{Prise en charge des crises convulsives}

Les anesthésiologistes (ayant la capacité de prendre en charge les voies aériennes) sont souvent appelés à traiter les convulsions chez les femmes présentant une éclampsie. Les anesthésiologistes peuvent utiliser un bolus intraveineux de propofol $0,5-1 \mathrm{mg} \cdot \mathrm{kg}^{-1}$ ou de midazolam $2-4 \mathrm{mg}$ pour interrompre rapidement une crise dans la population générale. Bien que les anesthésiologistes connaissent bien leur utilisation, il n'existe aucune donnée factuelle publiée pour guider l'utilisation du midazolam ou du propofol en cas d'éclampsie. Les manuels standard d'anesthésie décrivent la protection cérébrale potentielle ainsi que les propriétés anti-convulsivantes du propofol, et des présentations de cas indiquent son efficacité pour interrompre les crises, particulièrement en cas d'état de mal épileptique lié aux THG. ${ }^{23-25}$ Étant donné que la plupart des crises éclamptiques sont de courte durée et répondent rapidement au sulfate de magnésium, il faut 
garder à l'esprit le potentiel de sédation excessive, d'état post-ictal prolongé, ou la perte des réflexes de protection des voies aériennes en cas d'administration de propofol ou de midazolam lors d'une crise éclamptique typique. Si ces agents sont utilisés, leur administration ne devrait pas remplacer le bolus de $4 \mathrm{~g}$ de sulfate de magnésium.

\section{Volémie et prise en charge liquidienne}

Tableau hémodynamique d'une prééclampsie non traitée

Il est généralement reconnu que les femmes présentant une prééclampsie manifestent une contraction volumique intravasculaire (pressions veineuses centrales [PVC] basses et résistance vasculaire systémique plus élevée que la norme pendant la grossesse) avec un tonus sympathique élevé et un débit cardiaque (DC) au-dessus de la norme. Grâce aux nouvelles technologies tels que les moniteurs non invasifs de l'hémodynamie et l'échocardiographie, la notion de contraction volumique intravasculaire chez les femmes souffrant de THG est aujourd'hui mise en doute. ${ }^{26}$ Crozier et coll. ont récemment suggéré que les pressions droites sont basses à cause d'un cœur très efficace et d'un DC considérablement accru. ${ }^{26}$

Un tel modèle pourrait expliquer la faible corrélation entre la PVC et la pression capillaire pulmonaire observée en cas de prééclampsie, ${ }^{11,26}$ et pourquoi la PVC n'est pas une mesure utile du volume intravasculaire. Les directives de la SOGC et de l'ACOG recommandent toutes deux d'éviter les moniteurs invasifs de l'hémodynamie, sauf lorsqu'il y a perfusion d'agents vasoactifs ou dans les cas où l'accès vasculaire périphérique n'est pas optimal. ${ }^{5,6}$ Des moniteurs moins invasifs de l'hémodynamie (par ex. l'analyse de contour d'onde artérielle et la cardiographie d'impédance) ont été évalués dans des cas de prééclampsie et démontrent une corrélation avec des indices dérivés de la thermodilution. ${ }^{27}$ L'échocardiographie transthoracique procure aussi des informations structurelles et fonctionnelles concernant la fonction cardiaque et la réponse aux interventions. ${ }^{28,29}$

Dans une étude échocardiographique de l'hémodynamie maternelle, la prééclampsie d'apparition précoce (par opposition à une prééclampsie d'apparition tardive) a été associée à une résistance vasculaire totale plus élevée et à un DC plus bas, ce qui suggèrerait un état de remplissage bas et une surcharge de pression. ${ }^{30}$ Bien qu'aucune étude ne s'intéresse spécifiquement aux différences entre les deux sous-types en réponse au travail obstétrical et à l'anesthésie neuraxiale, on observe une altération plus exagérée de la physiologie cardiovasculaire et une tendance plus élevée à une défaillance multisystémique dans les cas de prééclampsie d'apparition précoce.

\section{Prise en charge du volume intravasculaire, œdème pulmonaire et insuffisance rénale}

Les femmes atteintes de prééclampsie sont enclines aux œdèmes interstitiels, et $3 \%$ des cas peuvent souffrir d'un œdème pulmonaire, lequel est associé à une mortalité et une morbidité significatives. ${ }^{31}$ Une politique de restriction liquidienne chez les patientes présentant des THG est communément acceptée et a permis de réduire le nombre de cas d'œdème pulmonaire. ${ }^{5,6,11}$ Ainsi, une expansion du volume plasmatique total à l'aide de solutions cristalloïdes ou colloïdes n'est pas recommandée chez les femmes qui présentent une prééclampsie. ${ }^{5,6,11}$ La prise intraveineuse et orale devrait être minimisée et surveillée. En l'absence d'atteinte rénale préexistante ou d'augmentation du taux sérique de créatinine, une oligurie à $<15 \mathrm{~mL} \cdot \mathrm{h}^{-1}$ peut être tolérée pour six heures consécutives sans créer de complication importante. Le furosémide devrait être réservé pour le traitement de l'œdème pulmonaire. ${ }^{5,6}$

Lorsqu'il y a THG, on définit l'insuffisance rénale évolutive comme une créatinine $>150 \mathrm{mg} \cdot \mathrm{dL}^{-1}$ ou un doublement du taux sérique de créatinine en l'absence d'autre atteinte rénale préexistante; elle est considérée comme une indication maternelle pour la tenue d'un accouchement immédiat. ${ }^{5,6,11}$ Entre 2003 et 2010, les taux d'insuffisance rénale aiguë obstétricale ont significativement augmenté au Canada chez les femmes atteintes de THG, particulièrement chez celles présentant une protéinurie significative. ${ }^{32}$ Parmi les facteurs contributeurs suggérés, citons une mauvaise prise en charge liquidienne, les interactions médicamenteuses (antihypertenseurs, anti-inflammatoires non stéroïdiens, statines) et l'hémorragie postpartum.

\section{Rôle et prise en charge de l'analgésie du travail obstétrical}

Une analgésie péridurale pour le travail obstétrical est fortement recommandée chez les femmes présentant une prééclampsie. ${ }^{5,6,11}$ En l'absence des contre-indications habituelles (en particulier la coagulopathie), l'analgésie péridurale s'est avérée sécuritaire et efficace pour atténuer la réponse sympathique à la douleur du travail obstétrical, réduire la consommation d'oxygène et procurer un mode d'anesthésie neuraxial sécuritaire et rapide en cas d'accouchement opératoire. ${ }^{33}$ Il convient donc d'envisager la pose précoce d'un cathéter péridural avant que la numération plaquettaire ne se réduise au fil de 
l'évolution de la maladie. Il s'agit là d'un élément important de la stratégie visant à éviter l'anesthésie générale chez cette population de patientes. Le moment du retrait du cathéter péridural en postpartum doit également être évalué avec soin, étant donné qu'il peut déranger les vaisseaux paravertébraux. Lorsqu'une analgésie péridurale n'est pas possible, les narcotiques parentéraux constituent l'alternative recommandée., ${ }^{5,6}$

Une activation plaquettaire excessive en raison d'un dysfonctionnement endothélial est l'une des caractéristiques principales du modèle physiopathologique de la prééclampsie. ${ }^{9}$ Ceci entraîne une augmentation de la séquestration plaquettaire et une réduction du taux de plaquettes dans la circulation. La gravité de la thrombopénie en cas de prééclampsie dépend de la gravité de la maladie et de la présence ou non de décollement placentaire. ${ }^{11}$ Les hématomes rachidiens et périduraux sont des complications rares mais bien connues de l'anesthésie neuraxiale chez les femmes dont l'hémostase est déséquilibrée, cependant l'incidence globale de saignements paravertébraux associés aux techniques neuraxiales est plus faible dans la population obstétricale que dans la population non obstétricale. ${ }^{27,33}$

Chez les parturientes atteintes de prééclampsie, la mesure de la numération plaquettaire est recommandée dès l'admission à l'unité de travail obstétrical. ${ }^{5,6,11}$ Le taux plaquettaire absolu considéré comme « sécuritaire » pour réaliser une technique neuraxiale demeure controversé, mais dans une étude de thromboélastographie d'échantillons sanguins chez des femmes présentant une prééclampsie, aucune détérioration de la coagulation n'a été observée lors de taux plaquettaires supérieurs à $75 \times$ $10^{-9} \cdot \mathrm{L}^{-1} .^{33}$ En l'absence d'une thrombopénie inférieure à $100 \times 10^{-9} \cdot \mathrm{L}^{-1}$ et sans preuves cliniques d'une hémorragie, aucune évaluation de laboratoire supplémentaire de l'hémostase n'est nécessaire. ${ }^{27}$ Étant donné la possibilité d'une détérioration rapide chez les patientes atteintes de prééclampsie, si le taux de plaquettes chute au-dessous de $100 \times 10^{-9} \cdot \mathrm{L}^{-1}$, il faut réaliser des mesures en série de numération plaquettaire, de même que les indices de coagulation et les taux de fibrinogènes. ${ }^{27}$

Un traitement à base de corticostéroïdes peut améliorer le nombre de plaquettes et les indices biochimiques; toutefois, bien que fréquemment administré pour accélérer la maturité des poumons fœetaux, ce traitement n'est pas recommandé pour prendre en charge un syndrome HELLP à l'heure actuelle. ${ }^{6}$ On recommande la transfusion plaquettaire en cas de thrombopénie grave de $<49 \times$ $10^{-9} \cdot \mathrm{L}^{-1}$ dans le cadre d'un accouchement par césarienne, et lorsque $<20 \times 10^{-9} \cdot \mathrm{L}^{-1}$ indépendamment du mode d'accouchement. ${ }^{6}$ Lors de tout saignement clinique, il faut procéder à une évaluation détaillée de l'hémostase, étant donné la prévalence élevée de CIVD et l'hypofibrinémie qui s'ensuit. Dans notre pratique, une mesure directe de la tension artérielle à l'aide d'une canule artérielle radiale (ou d'une autre artère) facilite le monitorage hémodynamique et l'échantillonnage sanguin, ce qui permet une réévaluation fréquente chez les parturientes présentant un déséquilibre grave de la fonction hépatique et de l'hémostase.

Dans chaque cas, les anesthésiologistes devraient évaluer minutieusement le risque d'une complication rare mais potentiellement dévastatrice d'hématome rachidien par rapport aux nombreux avantages d'une anesthésie neuraxiale chez la patiente prééclamptique.

\section{L'anesthésie pour l'accouchement opératoire}

Il est généralement accepté que les intubations difficiles et les échecs d'intubation sont plus fréquents chez les femmes atteintes de THG. $^{15}$ En outre, le stimulus de la laryngoscopie ajoute le risque de déclencher une crise hypertensive et une lésion vasculaire cérébrale. Sauf indication contraire, l'anesthésie neuraxiale est à privilégier chez les femmes atteintes de prééclampsie. En raison de sa rapidité d'action et du calibre moins traumatisant de l'aiguille, la rachianesthésie est à préférer à une péridurale de novo en cas d'accouchement par césarienne. L'hypotension post-rachidienne est moins fréquente et moins grave chez les femmes prééclamptiques que chez les parturientes en bonne santé. ${ }^{27}$

Si l'on choisit une anesthésie générale en raison d'une urgence ou de contre-indications existantes, il est impératif d'anticiper et de contrôler la réponse hypertensive à la laryngoscopie. ${ }^{5}$ Il n'existe pas suffisamment de données probantes pour recommander un agent en particulier pour prévenir la réponse hypertensive pendant la laryngoscopie, mais l'esmolol, la nitroglycérine et le labétalol (lors de cas non urgents) ont tous été associés à de bons résultats. À l'heure actuelle, on ne recommande pas de bolus de lidocaïne ou de sulfate de magnésium pour prévenir la réponse hypertensive à la laryngoscopie chez les femmes souffrant de THG. ${ }^{5,6}$ Certains praticiens évitent les narcotiques pendant une séquence d'induction de routine lors d'une anesthésie générale obstétricale; toutefois, dans les cas de prééclampsie grave, une induction neuroprotectrice pourrait justifier l'utilisation judicieuse d'un agent narcotique intraveineux et ce, malgré le risque de dépression respiratoire néonatale. Bien que cet agent ne soit pas mentionné spécifiquement dans les directives, il a été démontré que le rémifentanil, à des doses $>1 \mu \mathrm{g} \cdot \mathrm{kg}^{-1}$, était fiable pour atténuer la réponse à la laryngoscopie tout en ne provoquant d'hypotension que dans un petit nombre de cas. ${ }^{34,35}$ 
La réponse hémodynamique aux vasopresseurs des patientes prééclamptiques peut être exagérée, et l'hypotension devrait être facile à corriger à l'aide de petites doses incrémentielles de phényléphrine ou d'éphédrine sans complications pour le fœtus. ${ }^{5,27}$ L'innocuité et les conséquences pour le nouveau-né d'une perfusion prophylactique de phényléphrine, qui fait désormais partie de la prévention usuelle de l'hypotension post-rachidienne, n'ont pas encore été évaluées chez les femmes présentant une prééclampsie. ${ }^{11,27}$ La directive de la SOGC préconise de ne pas donner de charge volumique de routine lors de l'amorce du bloc neuraxial chez ces patientes. Nous n'avons trouvé aucune étude examinant la prise en charge liquidienne des femmes prééclamptiques recevant une anesthésie ou une analgésie neuraxiale. Toutefois, il semble que la stratégie de prise en charge liquidienne restrictive se fonde sur deux arguments: d'une part, une charge liquidienne ne prévient pas l'hypotension survenant après une rachianesthésie et son effet sur les pressions de remplissage centrales est bref; d'autre part on remarque une incidence accrue d'œdème pulmonaire lorsqu'on préconise une administration liquidienne libérale. , 23,25 $^{6}$

\section{Problèmes liés à l'anesthésie en période postpartum}

Un nombre considérable de parturientes présentant une hypertension anténatale demeureront hypertendues en postpartum, ce qui nécessitera occasionnellement l'amorce d'un traitement antihypertensif pendant la puerpéralité. Les femmes qui développent une hypertension de novo en postpartum peuvent souffrir de dysfonctionnements d'organes cibles jusqu'à trois semaines après l'accouchement. 5,6 Il n'y a pas de consensus quant au choix d'agent hypertensif postpartum; en effet, bon nombre de ces agents, y compris les inhibiteurs de l'angiotensine, sont acceptables pendant l'allaitement.

La directive de la SOGC recommande de ne pas prescrire d'agents anti-inflammatoires non stéroïdiens (AINS) aux patientes dont l'hypertension s'aggrave, ni à celles présentant des taux élevés de créatinine ou une thrombopénie. Un compte rendu rétrospectif publié après cette directive n'a observé aucun effet secondaire néfaste associé à l'utilisation d'AINS en postpartum chez des patients présentant de graves troubles hypertensifs de la grossesse. ${ }^{36}$ Selon nous, une analgésie postpartum optimale joue un rôle essentiel pour minimiser l'hypertension postpartum; toutefois, il faut faire attention lorsqu'on prescrit une telle analgésie aux patientes qui manifestent une atteinte rénale plus importante ou dont la maladie est plus grave. Chez les patientes présentant des signes clairs de lésion rénale persistante ou une thrombopénie, il convient de ne pas prescrire d'analgésie à base d'AINS jusqu'à confirmation de la résolution des dysfonctionnements des organes cibles.

Même lorsque des femmes souffrant de THG sont normotendues en période postpartum, une évaluation minutieuse et un suivi à long terme sont recommandés. En effet, elles pourraient bénéficier d'une évaluation des facteurs traditionnels de risque cardiovasculaire. Il convient d'informer ces patientes qu'elles courent un risque accru à long terme d'hypertension, de morbidité cardiovasculaire et vasculaire cérébrale, de mortalité, de néphropathie, de thromboembolie, d'hypothyroïdisme, et de diabète de type $2.5,6,37$

Il existe de plus en plus de données probantes attestant que les femmes pourraient souffrir d'un état de stress post-traumatique (ESPT) pendant plusieurs années postpartum, particulièrement après une hospitalisation maternelle prolongée. Les professionnels de la santé doivent porter une attention spéciale à tout symptôme d'ESPT et rapidement référer ces femmes afin qu'elles soient évaluées et traitées. ${ }^{5,6}$

\section{Résumé}

L'incidence des THG augmente au Canada et dans le monde, et cette tendance va probablement se poursuivre à l'avenir. Les anesthésiologistes font aujourd'hui partie intégrante des équipes multidisciplinaires qui prennent en charge les patientes enceintes hypertendues. La version la plus récente de la directive clinique de la SOGC aborde plusieurs points pertinents aux soins anesthésiques en cas de prééclampsie. En outre, la directive propose de nouvelles classifications et de nouveaux critères diagnostiques dont les objectifs sont d'anticiper la progression de la maladie et de garantir un traitement opportun et adapté.

Bien que notre expertise soit souvent recherchée, notamment pour le traitement de l'hypertension aiguë et grave, la prise en charge liquidienne, l'analgésie pour le travail obstétrical, l'anesthésie en cas d'accouchement opératoire et le maintien des organes de la mère, il est essentiel de bien comprendre l'évolution de la maladie et d'être au fait des directives régissant les soins obstétricaux, si l'on veut offrir des soins de qualité aux patientes atteintes de cette maladie potentiellement fatale.

\section{Cas clinique}

On vous demande de prendre en charge l'anesthésie pour l'accouchement par césarienne d'une primipare (G1P0) de 24 ans, à 32 semaines de gestation. La patiente ne présente 
pas d'antécédents pré-grossesse concernant sa tension artérielle (TA). Elle a eu un épisode d'hypertension à 26 semaines, diagnostiqué comme une hypertension transitoire. Au cours des dernières 24 heures, toutefois, sa TA est élevée (150/100) et elle a reçu une dose unique de $200 \mathrm{mg}$ de labétalol oral et des corticostéroïdes. Elle vient d'être admise dans votre unité de naissance et souffre maintenant de maux de tête, de nausée, de douleur au quadrant supérieur droit, et ses tests de fonction hépatique sont élevés. Aujourd'hui, la surveillance fotale par échographie révèle un retard de croissance intra-utérin et l'absence de débit télédiastolique dans l'artère ombilicale. Votre collègue obstétricien rapporte que le col de la patiente n'est pas favorable à un accouchement vaginal, et elle nécessite une césarienne urgente. Elle est à jeun depuis quatre heures et a récemment reçu deux doses intraveineuses de labétalol.

Ses signes vitaux actuels sont une TA de 164/102 $\mathrm{mmHg}$, une fréquence cardiaque de 90 battements.min-1, un rythme sinusal normal, une $\mathrm{SpO} 2$ à $96 \%$ et une fréquence cardiaque foetale de $130 \cdot \mathrm{min}^{-1}$. Son indice de masse corporel est de $36 \mathrm{~kg} \cdot \mathrm{m}^{-2}$.

L'examen des voies aériennes est favorable, avec Mallampati de classe 2, une ouverture buccale $>4 \mathrm{~cm}$, une distance thyro-mentonnière $>6 \mathrm{~cm}$ et une bonne avancée mandibulaire.

Une formule sanguine complète, réalisée deux heures plus tôt, a révélé un taux d'hémoglobine à $128 \mathrm{~g} \cdot \mathrm{L}^{-1}$, des plaquettes à $68 \times 10^{-9} \cdot \mathrm{L}^{-1}$, et des tests de la fonction hépatique élevés stables: aspartate aminotransférase (ASAT) 130, alanine aminotransférase (ALAT) 90, et lacticodéshydrogénase (LDH) 500.

\section{Directives pour compléter le module de développement professionnel continu (DPC):}

1. Lisez cet article et les références en gras.

2. Allez à: http://www.cas.ca/Members/CPD-Online et choisissez le module actuel: Les troubles hypertensifs de la grossesse.

3. Répondez aux questions à choix multiples portant sur le cas clinique.

4. Une fois que vous aurez répondu à toutes les questions, vous aurez accès aux explications d'experts pour tous les choix possibles.

5. Les participants peuvent réclamer un maximum de quatre heures de DPC pour un total de 12 crédits sous la Section 3 du programme de DPC du Collège royal des médecins et chirurgiens du Canada.

Acknowledgements This manuscript was completed at the IWK Health Centre. The authors sincerely thank Dr. Victoria M. Allen,
Department of Obstetrics \& Gynaecology, Dalhousie University for her expert manuscript review. We also thank Ms. Kimberly Vella for her assistance with the literature search and administrative support.

Conflicts of interest None declared.

Editorial responsibility This submission was handled by Dr. A. Stéphane Lambert, CPD Editor, Canadian Journal of Anesthesia.

Remerciements Ce manuscrit a été rédigé au IWK Health Centre. Les auteurs remercient sincèrement la Dre Victoria $M$. Allen, du département d'obstétrique et de gynécologie de l'Université Dalhousie, pour sa révision experte du manuscrit. Nous remercions également Mme Kimberly Vella pour son aide pour la recherche de littérature et son soutien administratif.

\section{Conflit d'intérêt Aucun.}

Responsabilité éditoriale Cet article a été traité par Dr. A. Stéphane Lambert, rédacteur des DPC, Journal canadien d'anesthésie.

\section{References}

1. Carty DM, Delles $C$, Dominiczak $A F$. Preeclampsia and future maternal health. J Hypertens 2010; 28: 1349-55.

2. Public Health Agency of Canada. Maternal hypertension in Canada. Ottawa: Public Health Agency of Canada, Canadian Perinatal Surveillance System; Available from URL: http://www. phac-aspc.gc.ca/rhs-ssg/factshts/index-eng.php (accessed May 2016).

3. Auger N, Luo ZC, Nuyt AM, et al. Secular trends in preeclampsia incidence and outcomes in a large Canada database: a longitudinal study over 24 years. Can J Cardiol 2016. doi:10. 1016/j.cjca.2015.12.011.

4. Public Health Agency of Canada. Maternal morbidity in Canada. Ottawa: Public Health Agency of Canada, Canadian Perinatal Surveillance System; 2011. Available from URL: http://www. phac-aspc.gc.ca/rhs-ssg/index-eng.php (accessed May 2016).

5. Magee LA, Pels A, Helewa M, Rey E, von Dadelszen P; Canadian Hypertensive Disorders of Pregnancy (HDP) Working Group. Diagnosis, evaluation, and management of the hypertensive disorders of pregnancy. Pregnancy Hypertens 2014; 4: 105-45.

6. Magee LA, Pels A, Helewa M, Rey E, von Dadelszen P; Canadian Hypertensive Disorders of Pregnancy Working Group. Diagnosis, evaluation, and management of the hypertensive disorders of pregnancy: executive summary. J Obstet Gynaecol Can 2014; 36: 416-41.

7. English FA, Kenny LC, McCarthy FP. Risk factors and effective management of preeclampsia. Integr Blood Press Control 2015; 8: 7-12.

8. Khan KS, Wojdyla D, Say L, Gulmezoglu AM, Van Look PF. WHO analysis of causes of maternal death: a systematic review. Lancet 2006; 367: 1066-74.

9. Roberts $J M$, Bell MJ. If we know so much about preeclampsia, why haven't we cured the disease? J Reprod Immunol 2013; 99: $1-9$.

10. Raymond D, Peterson E. A critical review of early-onset and lateonset preeclampsia. Obstet Gynecol Surv 2011; 66: 497-506.

11. American College of Obstetricians and Gynecologists; Task Force on Hypertension in Pregnancy. Hypertension in 
pregnancy. Report of the American College of Obstetricians and Gynecologists' Task Force on Hypertension in Pregnancy. Obstet Gynecol 2013; 122: 1122-31.

12. National Institute for Health and Clinical Excellence. Hypertension in pregnancy: diagnosis and management. NICE Clinical Guideline 107. London: Excellence. National Institute for Health and Clinical Excellence; 2010. Available from URL: https://www.nice.org.uk/guidance/cg107 (accessed May 2016).

13. Committee on Obstetric Practice. Committee Opinion No. 623: Emergent therapy for acute-onset, severe hypertension during pregnancy and the postpartum period. Obstet Gynecol 2015; 125 : 521-5.

14. Haram K, Svendsen E, Abildgaard U. The HELLP syndrome: clinical issues and management. A Review. BMC Pregnancy Childbirth 2009; 9: 8.

15. Mol BW, Roberts CT, Thangaratinam S, Magee LA, de Groot CJ, Hofmeyr GJ. Pre-eclampsia. Lancet 2016; DOI: 10.1016/ S0140-6736(15)00070-7.

16. Koopmans $C M$, Bijlenga D, Groen $H$, et al. Induction of labour versus expectant monitoring for gestational hypertension or mild pre-eclampsia after 36 weeks' gestation (HYPITAT): a multicentre, open-label randomised controlled trial. Lancet 2009; 374: 979-88.

17. Broekhuijsen $K$, van Baaren GJ, van Pampus $M G$, et al. Immediate delivery versus expectant monitoring for hypertensive disorders of pregnancy between 34 and 37 weeks of gestation (HYPITAT-II): an open-label, randomised controlled trial. Lancet 2015; 385 : 2492-501.

18. Euser AG, Cipolla MJ. Magnesium sulfate for the treatment of eclampsia: a brief review. Stroke 2009; 40: 1169-75.

19. Martin JN Jr, Thigpen BD, Moore RC, Rose CH, Cushman J, May $W$. Stroke and severe preeclampsia and eclampsia: a paradigm shift focusing on systolic blood pressure. Obstet Gynecol 2005; 105: 246-54.

20. Snyder SW, Cardwell MS. Neuromuscular blockade with magnesium sulfate and nifedipine. Am J Obstet Gynecol 1989; 161: $35-6$

21. Ben-Ami M, Giladi Y, Shalev E. The combination of magnesium sulphate and nifedipine: a cause of neuromuscular blockade. Br J Obstet Gynaecol 1994; 101: 262-3.

22. Magee LA, Miremadi S, Li J, et al. Therapy with both magnesium sulfate and nifedipine does not increase the risk of serious magnesium-related maternal side effects in women with preeclampsia. Am J Obstet Gynecol 2005; 193: 153-63.

23. Bateman BT, Polley LS. Hypertensive disorders. In: Chestnut DH, Wong CA, Tsen LC, Ngan Kee WD, Beilin Y, Mhyre J (Eds). Chestnut's Obstetric Anesthesia: Principles and Practice, 5th ed. Philadelphia: Saunders; 2014: 825-59.
24. Matrooshi N, Ali N, Abdalla MS, Pathikkaran PA, Sinha S. Propofol for status epilepticus in pregnancy. J Neurol Stroke 2015; 3: 00108.

25. Dam AK, Mishra JC, Shome PK. Treatment of refractory seizures in eclampsia with propofol: a case report. Indian J Crit Care Med 2003; 7: 283-4.

26. Crozier TM, Wallace EM, Parkin WG. Haemodynamic assessment in pregnancy and pre-eclampsia: a Guytonian approach. Pregnancy Hypertens 2015; 5: 177-81.

27. Henke $V G$, Bateman BT, Leffert LR. Focused review: spinal anesthesia in severe preeclampsia. Anesth Analg 2013; 117: 68693.

28. Dennis AT. Management of pre-eclampsia: issues for anaesthetists. Anaesthesia 2012; 67: 1009-20.

29. DesRoches JM, McKeen DM, Warren A, et al. Anesthetic management guided by transthoracic echocardiography during cesarean delivery complicated by hypertrophic cardiomyopathy. A A Case Rep 2015; 6: 154-9.

30. Valensise H, Vasapollo B, Gagliardi G, Novelli GP. Early and late preeclampsia: two different maternal hemodynamic states in the latent phase of the disease. Hypertension 2008; 52: 873-80.

31. Cantwell R, Clutton-Brock T, Cooper G, et al. Saving Mothers' Lives: Reviewing maternal deaths to make motherhood safer: 2006-2008. The Eighth Report of the Confidential Enquiries into Maternal Deaths in the United Kingdom. BJOG 2011; 118(Suppl 1): $1-203$

32. Mehrabadi A, Liu S, Bartholomew S, et al. Hypertensive disorders of pregnancy and the recent increase in obstetric acute renal failure in Canada: population based retrospective cohort study. BMJ 2014; 349: g4731.

33. Leffert LR. What's new in obstetric anesthesia? Focus on preeclampsia. Int J Obstet Anesth 2015; 24: 264-71.

34. Park BY, Jeong CW, Jang EA, et al. Dose-related attenuation of cardiovascular responses to tracheal intubation by intravenous remifentanil bolus in severe pre-eclamptic patients undergoing Caesarean delivery. Br J Anaesth 2011; 106: 82-7.

35. Yoo KY, Kang DH, Jeong $\mathrm{H}$, et al. A dose-response study of remifentanil for attenuation of the hypertensive response to laryngoscopy and tracheal intubation in severely preeclamptic women undergoing caesarean delivery under general anaesthesia. Int J Obstet Anesth 2013; 22: 10-8.

36. Wasden SW, Ragsdale ES, Chasen ST, Skupski DW. Impact of non-steroidal anti-inflammatory drugs on hypertensive disorders of pregnancy. Pregnancy Hypertens 2014; 4: 259-63.

37. Wilson BJ, Watson MS, Prescott GJ, et al. Hypertensive diseases of pregnancy and risk of hypertension and stroke in later life: results from cohort study. BMJ 2003; 326: 845. 